\title{
ANL-78-108
}

\section{MEMBRANE OXYGEN ENRICHMENT COST AND APPLICATION EVALUATION}

by

Jack Fischer and Lowell J. Burnett

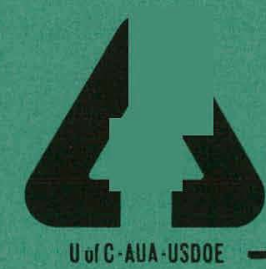

ARGONNE NATIONAL LABORATORY, ARGONNE, ILLINOIS

Operated for the U. S. DEPARTMENT OF ENERGY

under Contract W-31-109-Eng-38 


\section{DISCLAIMER}

This report was prepared as an account of work sponsored by an agency of the United States Government. Neither the United States Government nor any agency Thereof, nor any of their employees, makes any warranty, express or implied, or assumes any legal liability or responsibility for the accuracy, completeness, or usefulness of any information, apparatus, product, or process disclosed, or represents that its use would not infringe privately owned rights. Reference herein to any specific commercial product, process, or service by trade name, trademark, manufacturer, or otherwise does not necessarily constitute or imply its endorsement, recommendation, or favoring by the United States Government or any agency thereof. The views and opinions of authors expressed herein do not necessarily state or reflect those of the United States Government or any agency thereof. 


\section{DISCLAIMER}

Portions of this document may be illegible in electronic image products. Images are produced from the best available original document. 
The facilities of Argonne National Laboratory are owned by the United States Government. Under the terms of a contract (W-31-109-Eng-38) among the U. S. Department of Energy, Argonne Universities Association and The University of Chicago, the University employs the staff and operates the Laboratory in accordance with policies and programs formulated, approved and reviewed by the Association.

\section{MEMBERS OF ARGONNE UNIVERSITIES ASSOCIATION}

The University of Arizona Carnegie-Mellon University Case Western Reserve University

The University of Chicago

University of Cincinnati

Illinois Institute of Technology

University of Illinnis

Indiana University

The University of Iowa

Iowa State University
The University of Kansas Kansas State University

Loyola University of Chicago Marquette University The University of Michigan Michigan State University University of Minne sota University of Missouri Northwestern University University of Notre Dame
The Ohio State University Ohio University

The Pennsylvania State University Purdue University

Saint Louis University

Southern Illinois University The University of Texas at Austin Washington University

Wayne State University

The University of Wisconsin-Madison

\section{NOTICE}

This report was prepared as an account of work sponsored by the United States Government. Neither the United States nor the United States Department of Energy, nor any of their employees, nor any of their contractors, subcontractors, or their employees, makes any warranty, express or implied, or assumes any legal liability or responsibility for the accuracy, completeness or usefulness of any information, apparatus, product or process disclosed, or represents that its use would not infringe privately-owned rights. Mention of commercial products, their manufacturers, or their suppliers in this publication does notimply or connote approval or disapproval of the product by Argonne National Laboratory or the U. S. Department of Energy.

Printed in the United States of America

$$
\text { Available from }
$$

National Technical Information Service

U. S. Department of Commerce

5285 Port Royal Road

Springfield, Virginia 22161

Price: Printed Copy $\$ 5.25 ;$ Microfiche $\$ 3.00$ 
Distribution Categories:

Coal Conversion and Utilization-MHD (UC-90g)

Energy Conservation--Industry (UC-95f)

ANL - 78-108

ARGONNE NATIONAL LABORATORY

9700 South Case Avenue

Argonne, Illinois 60439

\section{MEMBRANE OXYGEN ENRICHMENT ÇOST}

AND APPLICATION EVALUATION

by

Jack Fischer and Lowell J. Burnett*

Chemical Engineering Division

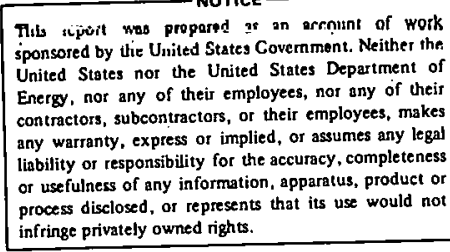

an

eir employees, makes

any warranty, expiess or implied, or assumes any hest

infringe privately owned rights.

March 1979

*Fluid Systems Division, UOP, Basic Development Department, 4901 Morena Boulevard, Suite 8006 , San Diego, California 92117. 


\section{THIS PAGE \\ WAS INTENTIONALLY \\ LEFT BLANK}


ABSTRACT . . . . . . . . . . . . . . . . . . . . 1

I. INTRODUCTION . . . . . . . . . . . . . . . . . . . 2

II. GAS SEPARATION WITH MEMBRANES . . . . . . . . . . . . 2

III. MEMBRANE DEVELOPMENT . . . . . . . . . . . . . . . . 5

A. Membrane Requirements and Materials . . . . . . . . 5

B. Spiral Wound Element . . . . . . . . . . . . 6

IV. APPLICATIONS AND COST ANALYSES . . . . . . . . . . . . . . 9

A. UOP Fluid Systems Division Analysis . . . . . . . . . 9

B. Econergy Analysis . . . . . . . . . . . . . 9

1. Conclusions . . . . . . . . . . . . . . . 9

2. Recommendations ............. 10

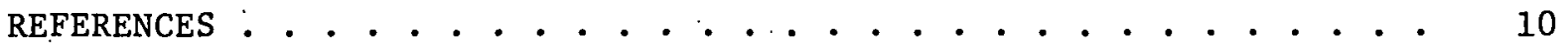

APPENDIXES

A. PRELIMINARY ANALYSIS OF MEMBRANE OXYGEN ENRICHMENT
ECONOMICS . . . . . . . . . . . . . . . . . . 11

B. AN ENGINEERING STUDY TO EVALUATE COSTS OF MEMBRANE GAS SEPARATION PROCESSES . . . . . . . . . . . . . 31 


\section{LIST OF FIGURES}

No.

1. Schematic of a Membrane Separation . . . . . . . . . . . . 3

2. Oxygen Flow Rate at 45 psi Versus Thin-Film Thickness for One Square Foot of Dimethyl Silicone Membrane .......... 6

3. Spiral-Wound Element Construction . . . . . . . . . . . 7

4. Spiral-Wound Separation Module Construction . . . . . . . 8

A-1. Oxygen Cost Versus Consumption Rate . . . . . . . . . . . . 14

$\bar{B}-1$. Process Flow Diagram for Vacuum Diffusion System . . . . . . 35

B-2. Process Flow Diagram for Pressure Diffusion System . . . . . . 36

B-3. MHD Power Cycle . . . . . . . . . . . . . . . . 43

S-1. Calculated Effect of Permeability Ratio $(\alpha)$ and Number of Stages on Limiting Oxygen Concentration in the Permeate . . . . 48

S-2. Calculated Effect of $R$ covery and Pressure Ratio on Oxygen Concentration in Permeate for $\alpha=2$ and Cocurrent Flow . . . . 49

S-3. Gas Diffusion Cell with Cocurrent Flow of Permeate and Residue . . . . . . . . . . . . . . . . . . . . . 49

S-4. Calculated Effect of Recovery and Pressure Ratio ( $\alpha$ ) on Oxygen Concentration in Permeate for $\alpha=7$. and Countercurrent Fluw . . . . . . . . . . . . . . . . . . . . 51

S-5. Gas Diffusion Cell with Countercurrent Flow of Permeate and Residue .................... 51

S-6. Calculated Effect of Recovery and Pressure Ratio ( $r$ ) on Oxygen Concentration in Permeate for $\alpha=2$ and Cross-Flow . . . . . 51

S-7. Gas Diffusion Cell with Cross-Flow of Permeate and Residue . . . 52

S-8. Effect of Pressure Ratio on Oxygen Content of Permeate at Zero Recovery ........................... 


\section{LIST OF TABLES}

No.

Title

$\underline{\text { Page }}$

1. Oxygen Permeabilities $\left(\mathrm{P}_{\mathrm{O}_{2}}\right)$ of Various Polymers . . . . . . . 4

2. Permeabilities. (P) and Selectivities of Binary Gas Mixtures in Dimethyl Silicone .. . . . . . . . . . . . . 4

A-1. System Parameters for 35\% oxygen Product. . . . . . . . . . 16

A-2. System Parameters for $30 \%$ oxygen Product . . . . . . . . . 17

A-3. System Parameters for 50\% 0xygen Product . . . . . . . . . 17

A-4. System Parameters for $40 \%$ Oxygen Product . . . . . . . . . . . 18

A-5. Capital Investment Required for an On-Site Cryogenic Oxygen Facility. . . . . . . . . . . . . . . . . . . 19

A-6. Capital Investment Required for a Membrane Oxygen Enrichment Facility $35 \% 0_{2}$ Product . . . . . . . . . . . . . . 20

A-7. Capital Investment Required for a Membrane Oxygen Enrichment Facility $30 \% 0_{2}$ Product . . . . . . . . . . . . . . 20

A-8. Capital Investment Required for a Membrane Oxygen Enrichment Facility, $50 \% 0_{2}$ Product . . . ............ . . 21

A-9. Capital Investment Required for a Membrane Oxygen Enrichment Facility, $40 \% 0_{2}$ Product . . . . . . . . . . . . . . . .

A-10. Power Required at a 1-(con/d) Production Level as a Function of Product Oxygen Composition . . . . . . . . . . . . 22

A-11. Total Estimated Cost Per Equivalent Ton for $35 \% \mathrm{O}_{2}$ Product . . 24

A-12. Tota1 Estimated Cost Per Equivalent Ton for $30 \%$ 0? Product. . . 25

A-13. Total Estimated Cost Per Equivalent Ton for 50\% $0_{2}$ Product . . 26

A-14. Total Estimated Cost Per Equivalent Ton for $40 \% 0_{2}$ Product . . 27

B-1. Capital Cost Estimate for Membrane Diffusion Plant . . . . . 38

B-2. Operating Cost Estimate for Membrane Diffusion Plant . . . . . 40

B-3. Comparison of Economics for Oxygen Enrichment . . . . . . . . 41

B-4. Effect of Oxygen Enrichment on MHD Steam Power Plant Requirements. . . . . . . . . . . . . . . . . . . 
MEMBRANE OXYGEN ENRICHMENT COST AND APPLICATION EVALUATION

by

Jack Fischer and Lowell J. Burnett

ABSTRACT

A separation process, similar to the reverse osmosis membrane process for the desalination of water, can be used for the separation and enrichment of multi-component gas streams. The development of new processing methods and modular packing systems together with advanced commercialization of desalination systems now makes similar processes for gas separation appear feasible and economical.

Composite membranes have been developed that are both thin enough to provide a large gas flow and strong enough to withstand the driving pressure of the incoming gas. This is done by depositing a polymer on the finely porous surface of a fabric-reinforced supportting membrane. The resulting material is then formed into a spiralwound element that provides a large amount of membrane area in a small, volume.

A very limited research and development activity has been directed toward the application of gas separation membrane systems. Potential applications of these systems include oxygen enrichment of air for improved combustion efficiencies for fossil fuels, nitrogen enrichment of air for applications requiring an inert atmosphere, helium recovery, separation of acid gases from fuel gases, and hydrogen enrichment in industrial proress app 1,isations. The uoc of oxygen-enriched alr in magnetohydrodynamics (MHD) and in blast furnaces are other potentially attractive applications.

Laboratory experiments using gas separation membranes by Fluid Systems Division of UOP and by General Electric Company have established the technical fcasibllity of using such membranes to produce oxygen-enriched air. A preliminary analysis of membrane oxygen enrichnent economics was prepared by the Fluid Systems Division of UOP which shows that oxygen enrichment could be profitable for combustion systems up to 100 tons of oxygen per day. A supporting economic study made by Econergy Associates reaffirms the positive economics potential for a 1000-ton/d, 30\% $0_{2}$ enrichment plant. 


\section{INTRODUCTION}

The objective of this project is to evaluate the use of oxygen enrichment using gas-permeable membranes for application in energy conservation processes. The Department of Energy-supported projects to which oxygenenrichment processes could be applicable are: fossil and alternate fuel combustion, coal gasification, fuel cells, and magnetohydrodynamics.

Recent advances in commercial membrane production and modular packaging make the use of membranes for gas separation and enrichment practical. A membrane process, similar to the reverse osmosis process used for desalination of sea water, can be used for the separation and enrichment of multi-component gas streams.

In the reverse osmosis membrane process, high-pressure saline water is placed in contact with a semipermeable membrane which is permeable lu waler but relatively impermeable to salt. The brine is concentrated at the surface of the membrane and eventually discarded. At present, the total world capacity of operating reverse osmosis equipment is approximately 65 million gallons per day. Over the past several years, an increasing share of research and development activity has been directed toward the development of gas membrane systems.

\section{GAS SEPARATION WITH MEMBRANES}

A membrane separation of a gas mixture is effected by passing a feed stream of the mixture across a membrane surface, as shown in Fig. 1 . The feed stream may be at 1 to 20 atm pressure, and the most permeable component of the mixture passes through the membrane at a faster rate than the least permeable component. Thus, the permeate stream, i.e., the output stream that has passed through the membrane, is enriched in the most permeable component. Conversely, the residue stream, $i . e$, the output stream that has passed over the membrane surface, is enriched in the least permeable component of the feed.

The ideal membrane for gas separation and enrichment applications would consist of a thin, imperfection-free sheet of a polymer material. The properties of this material would be such that a selected gas, or gases, could pass through it with little hindrance while all other gases would encounter a virtually impermeable barrier.

A11 polymer materials approximate this ideal behavior by exh1biting different permeabilities to different gases: In order for gas molecules to be transported across the barrier, they must first be absorbed into the polymer material. Once inside, their progress through the barrier is controlled by random diffusion. For this solution-diffusion model of gas transport, the gas permeability is given by: 


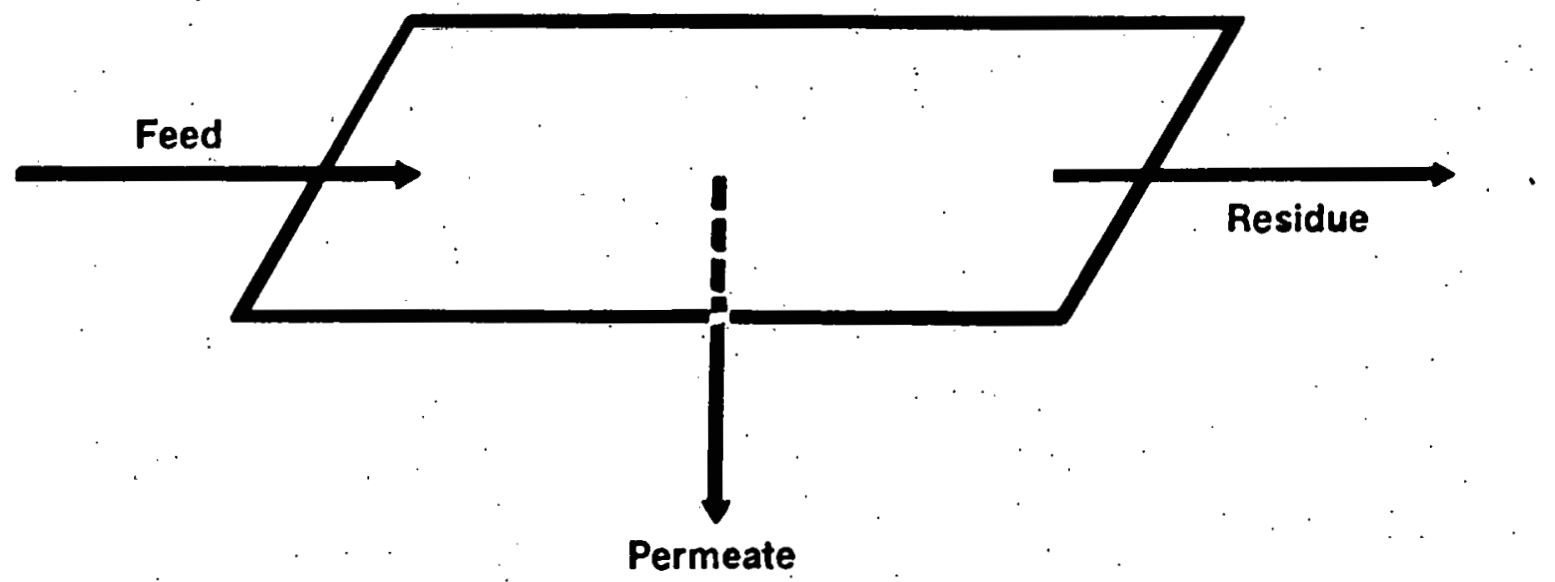

Fig. 1. Schematic of a Membrane Separation

$$
P=S \times D
$$

where

$$
\begin{aligned}
& \mathrm{P}=\text { Permeability } \\
& \mathrm{S}=\text { Solubility } \\
& \mathrm{D}=\text { Diffusion Constant }
\end{aligned}
$$
rate:

A similar phenomenological equation can be derived for the gas flow

$$
N=P A \frac{\Delta p}{t}
$$

where

$$
\begin{aligned}
\mathrm{N} & =\text { Gas flow rate } \\
\mathrm{P} & =\text { Permeability } \\
\mathrm{A} & =\text { Area } \\
\Delta \mathrm{p} & =\text { Pressure difference across membrane } \\
\mathrm{t} & =\text { Membrane thickness }
\end{aligned}
$$

Equation 2 can be used to predict the gas flow rate through a membrane of known thickness, area, and permeability at any given pressure. 
In a practical separation application, one of the most important parameters is the required membrane area. A survey of the gas permeation properties of polymers shows that dimethyl silicone is the likely material of choice for the minimization of membrane area. In a listing of oxygen permeability coefficients, $\mathrm{P}_{\mathrm{O}_{2}}$, for various polymers, given in Table 1 , dimethyl silicone rubber exhibits almost four times the permeability of polybutadiene.

The ability of a membrane to differentiate between two types of permeating gases is described by the membrane selectivity. This parameter, $\alpha$, is defined as a permeability ratio of two gases, $i . e ., \alpha=\mathrm{P}_{\mathrm{a}} / \mathrm{P}_{\mathrm{b}}$ for two gases $\mathrm{a}$ and $\mathrm{b}$. A tabulation of dimethyl silicone permeabilities and selectivities for several simple binary gas mixtures is given in Table 2 .

l'able 1. Oxygen Permeabilities $\left(\mathrm{P}_{\mathrm{O}_{2}}\right)$ of Various Polymers

\begin{tabular}{lc}
\hline \multicolumn{1}{c}{ Polymer } & $\mathrm{P}_{\mathrm{O}_{2}} \times 10^{9}, \mathrm{~cm} / \mathrm{s}$ \\
\hline Dimethyl Silicone Rubber & 50.0 \\
Silicone Polycarbonate Copolymer & 16.0 \\
Polybutadiene & 13.0 \\
Natural Rubber & 2.4 \\
Polyethylene, High Density & 0.1 \\
Cellulose Acetate & 0.08 \\
Nylon 6 & 0.004 \\
Teflon & 0.0004 \\
\hline
\end{tabular}

Table 2. Permeabilities (P) and Selectivities of Binary Gas Mixtures in Dimethyl Silicone

\begin{tabular}{lccc}
\hline Gas Pair, A/B & Permeab1lity, ratios, $\frac{P_{A}}{P_{B}}$ & Selectivity \\
\hline $\mathrm{O}_{2} / \mathrm{N}_{2}$ & $50 / 25$ & 2.0 \\
$\mathrm{CH}_{4} / \mathrm{He}$ & $80 / 30$ & 2.7 \\
$\mathrm{CO}_{2} / \mathrm{CH}_{4}$ & $\cdot$ & $270 / 80$ & 3.4 \\
$\mathrm{CO}_{2} / \mathrm{H}_{2}$ & $270 / 55$ & 4.9 \\
$\mathrm{H}_{2} \mathrm{O} / \mathrm{NH}_{3}$ & $3000 / 500$ & 6.0 \\
$\mathrm{CO}_{2} / \mathrm{CO}$ & $270 / 30$ & 9.0 \\
$\mathrm{NO}_{2} / \mathrm{NO}$ & $635 / 50$ & 12.7 \\
$\mathrm{CS}_{2} / \mathrm{N}_{2} \mathrm{O}$ & $7500 / 365$ & 20.6 \\
$\mathrm{H}_{2} \mathrm{~S} / \mathrm{CO}$ & $840 / 30$ & 28.0 \\
$\mathrm{SO}_{2} / \mathrm{N}_{2}$ & $1250 / 25$ & 50.0 \\
\hline
\end{tabular}




\section{MEMBRANE DEVELOPMENT}

\section{A. Membrane Requirements and Materials}

To provide a high flow rate for the selected gases, a real membrane must be extremely thin, ideally not more than a few hundred Angstroms thick. Conversely, the membrane must be extremely strong in order to withstand the driving pressure of the incoming gas stream. These requirements, of course, are incompatible and have led to the development of the thin-film composite membrane. Briefly stated, this membrane consists of a 250-500 $\AA$-dense layer of a polymer deposited on the finely porous surface of a fabric-reinforced supporting polymer membrane. In addition to providing a single thin active layer, this general method of composite membrane production provides several other advantages, including:

1. Independent selection of materials from which to prepare the thin semipermeable barrier and the finely porous supporting membrane.

2. Independent preparation of the thin film and the porous supporting membrane, thereby making it possible to optimize each component for its specific function.

3. Reproducible control over the thickness of the thin semipermeable barrier required to attain the theoretical maximum performance.

In the field of water treatment, recent advances in the development of composite membrane systems have made it possible to produce potable water from seawater in a single separation stage. In view of the superior performance, reliability, and apparent durability of the new thin-film composite membranes, plus the fact that they can be economically manufactured in quantity to rigid specifications, it is probable that these membranes will soon dominate the field of reverse osmosis. Because similar composite membranes have been made for gas separation, engineers feel that within a short time they can develop gas separation membranes which can be produced economically in quantity.

Fluid Systems and General Electric have made composite membranes for laboratory tests of gas separation and enrichment using thin-film barriers of dimethyl silicone. In 1957, Kammermeyer ${ }^{1}$ determined that, for common gases such as $\mathrm{H}_{2}, \mathrm{~N}_{2}, \mathrm{O}_{2}$, and $\mathrm{CO}_{2}$, silicone rubber was the most permeable polymer known. Robb, ${ }^{2}$ in 1967 , reported the permeation properties of silicone rubber for a wide variety of gases and vapors. He also identified the possibility of using silicone rubber, which is 2.2 times more permeable to oxygen than to nitrogen, to produce oxygen-enriched air from normal air.' As previously noted in Eq. (2), the flow rate of gas through the membrane at a given pressure is inversely proportional to the membrane thickness. The effect on flow rate of decreasing the barrier depth from $5000 \AA$ to $500 \AA$ is illustrated by the dashed and solid lines in Fig. 2. 


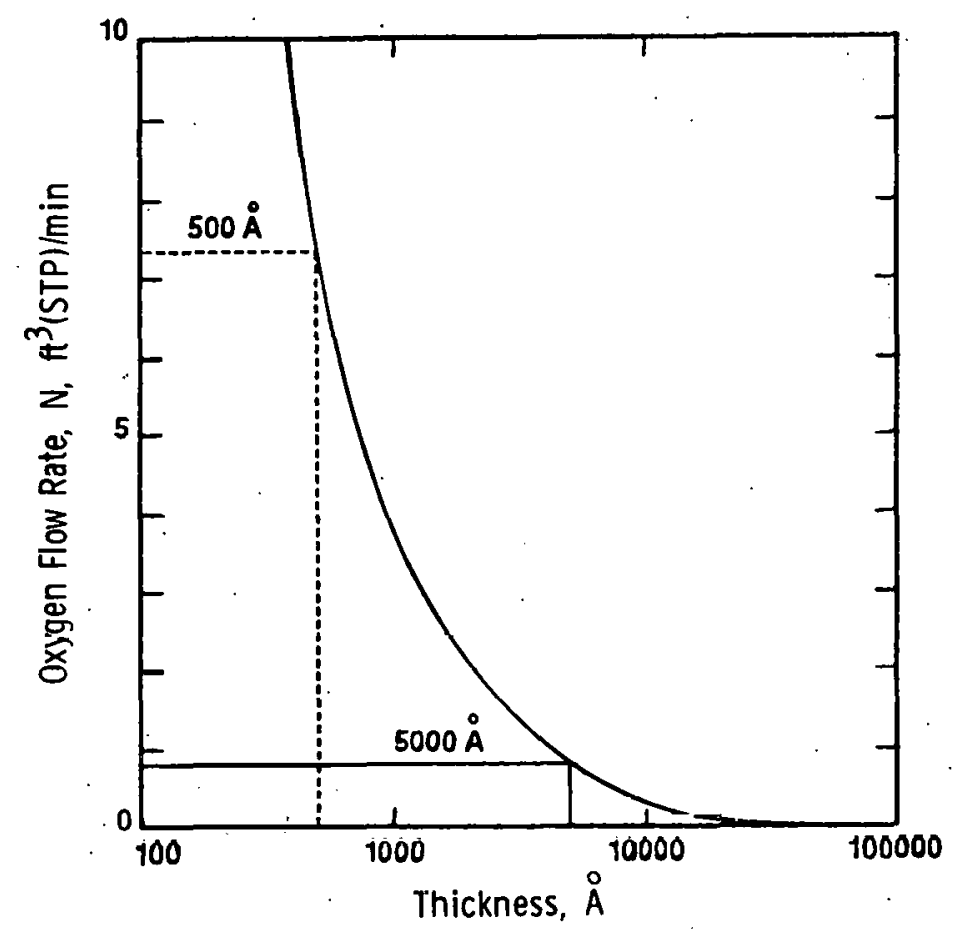

Fig. 2. Oxygen Flow Rate at 45 psi

Versus Thin-Film Thickness

for One Square Foot of Dimethyl

Silicone Membrane

\section{B. Spiral-Wound Element}

A great deal of research has been directed toward the development of efficient membrane packaging systems to be used in the economical desalination of seawater. One of the most unique and useful configurations developed for membrane packaging is the spiral-wound element. A schematic of the spiral-wound element is shown in Fig. 3 .

This element consists of two sheets of membrane separated by a porous support material. The material supports the membrane against the operating pressure and provides a flow path for the output. This "envelope" is sealed around three sides to prevent contamination of the product gases. The fourth edge is sealed to a hollow plastic tube which has perforations inside the edge seal area so that the product gases can be removed from the porous support material. This long "envelope" is rolled up about the central tube in the form of a splral, along with a mesh spacer that separates the facing membrane surfaces.

The spiral-wound element offers a number of advantages, including:

1. Large membrane surface area per unit volume.

2. Simple, rugged, disposable units. 


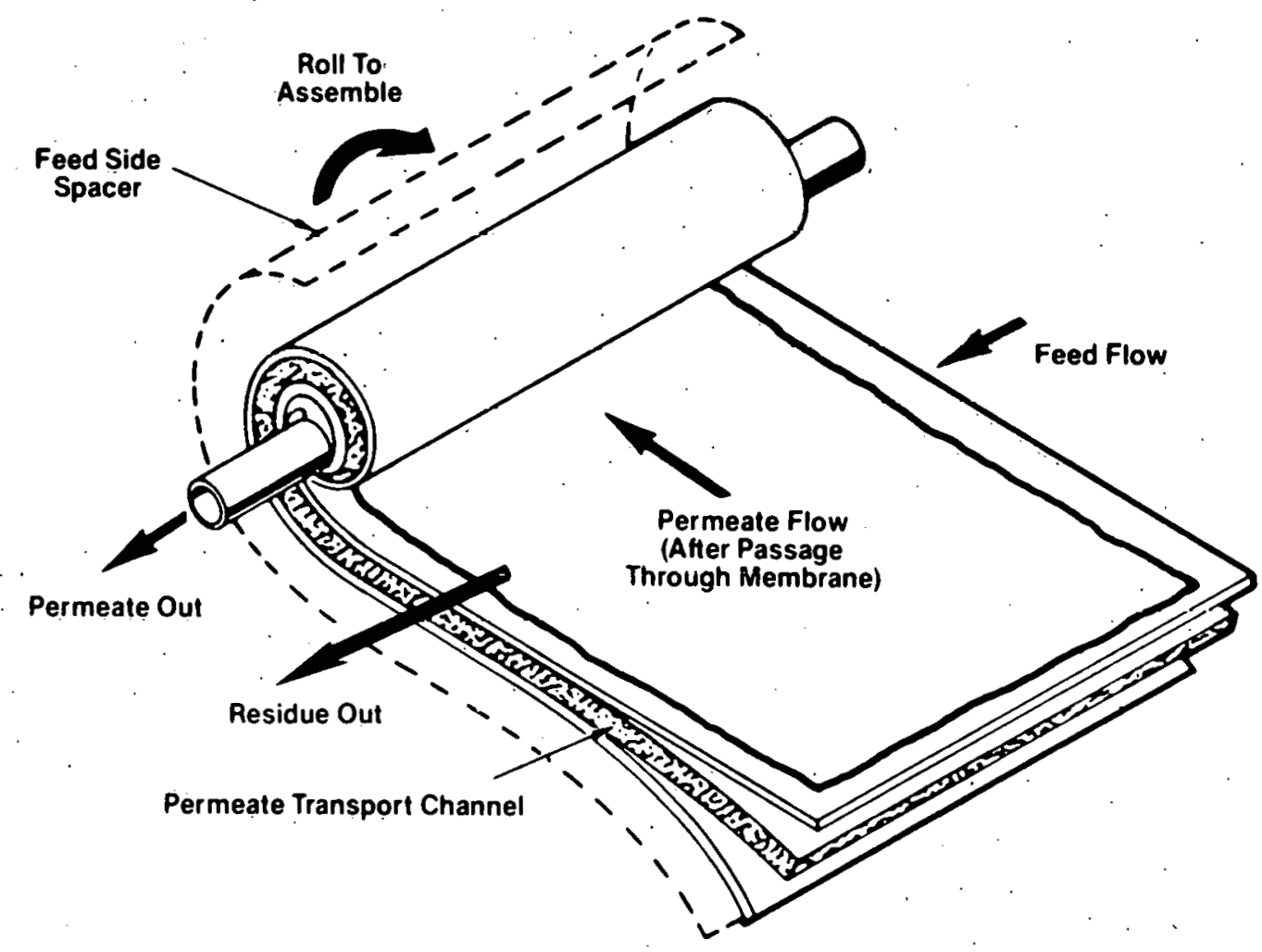

Fig. 3. Spiral-Wound Element Construction

3. Convenient and simple pressure vessel design and configuration, which lead to a compact modular plant arrangement.

4. Flexibility and ease in installation and in replacement of elements. Individual units can be easily replaced, and field installation of elements requires no special equipment or training.

To increase the packing density and to make most efficient use of the feed-gas volume, several such elements may be connected in series. These are then equipped with a peripheral seal and slipped into commercially available tubes that act as the pressure vessel. The entire assembiy is termed a "separation module" and is illustrated schematically in Fig. 4. 


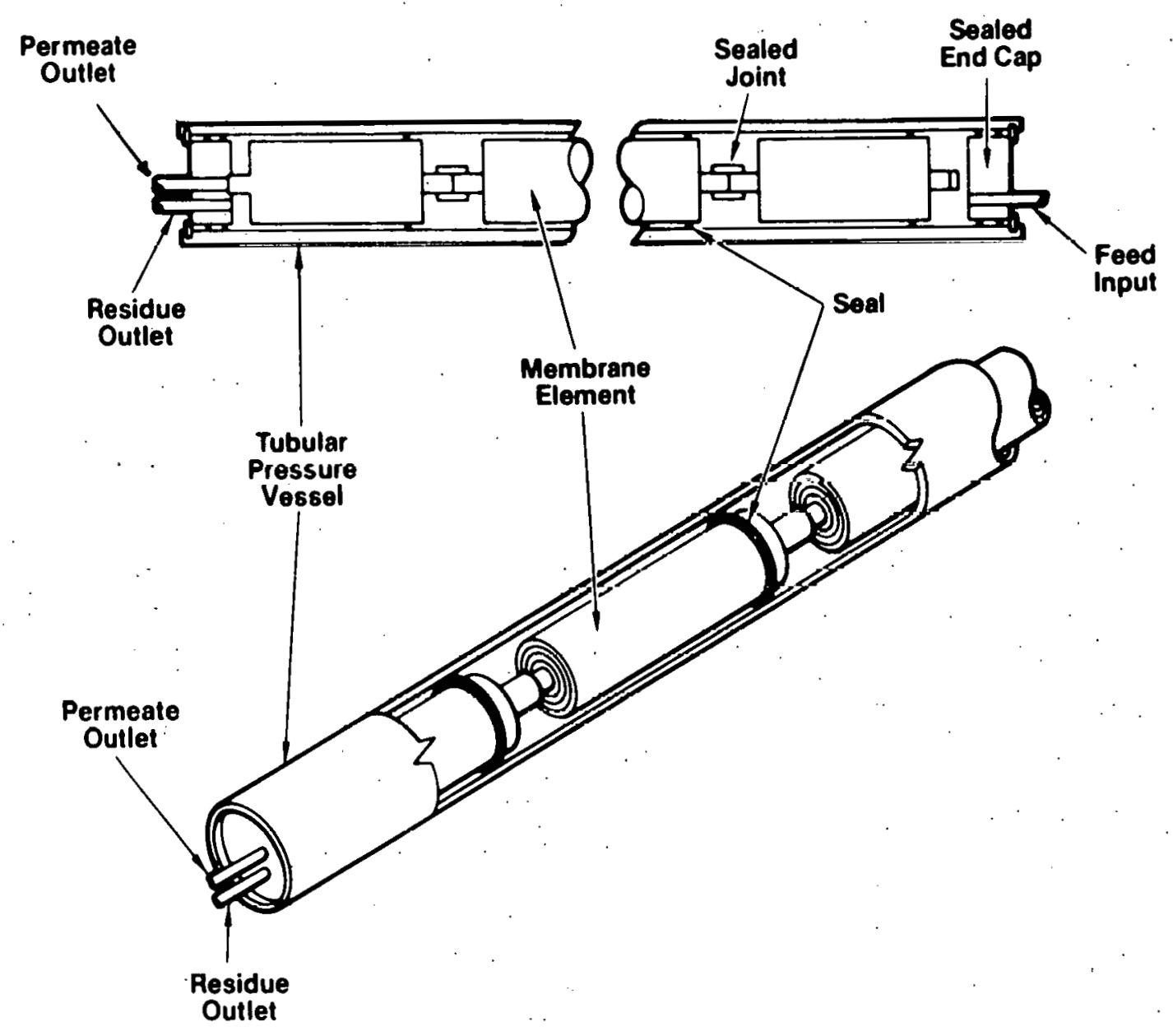

Fig. 4. Spiral-Wound Separation Module Construction

Development work is necessary with other polymers and variations in modular backing to increase the efficiency of gas separation and to increase the range of temperatures and pressures for various applications. Benchscale tests are required to establish the durability of the composite membranes and modular packages. Tests will be required over a range of temperature, pressure, and humidity. In addition, the effects of particulates and atmospheric gases such as $\mathrm{SO}_{2}, \mathrm{NO}_{\mathrm{x}}, \mathrm{NH}_{3}$, etc., have to be determined. 


\section{APPLICATIONS $\Lambda$ ND COST ANALYSES}

\section{A. UOP Fluid Systems Division Analysis}

In order to evaluate the use of enriched oxygen from a membrane separation process for a variety of applications, a preliminary analysis of membrane oxygen enrichment economics was made by $\mathrm{Dr}$. Lowell J. Burnett of Fluid Systems. This analysis is included as Appendix A of this report. The analysis showed that the estimated total cost of oxygen-enriched air is significantly less for the membrane-enrichment processes than for cryogenic oxygen-enrichment processes. Furthermore, the projected costs decrease with increasing membrane selectivity, a condition that also provides a more highly enriched product. Product cost appears to fall as the transmembrane pressure is lowered, though estimates were made only over a narrow range of operating conditions. However, reduction of the pressure difference across the membrane leads to a more dilute product, thus limiting its utility. As expected, an increase in membrane permeability also decreases the estimated cost of the product. The analysis made by L. Burnett was for enriched oxygen (30 to 50\% $0_{2}$ ) produced in quantities up to $100 \mathrm{ton} / \mathrm{d}$.

\section{B. Econergy Analysis}

The need for further evaluation of the costs of oxygen membrane enrichment and the potential for specific combustion applications was justified by the preliminary analysis. To accomplish this an engineering study was made for Argonne National Laboratory by Econergy Associates. This study is included in this report as Appendix B. Econergy Associates'conclusions and recommendations are as follows:

\section{Conclusions}

(1) The membrane diffusion process is competitive with liquid air separation for producing oxygen-enriched air. The estimated capital advantage is 3.8-4.1 million dollars for 1000 ton/d oxygen as $30 \% 0_{2}$. The bottomline cost advantage is 2.11 to $\$ 3.68$ per ton $0_{2}$.

(2) Oxygen enrichment has a potential market in

$\mathrm{MHD}$ power generation $\left(14,000\right.$ ton $/ \mathrm{d} \mathrm{O}_{2}$ for $\left.1000 \mathrm{MW}\right)$.

Iron blast furnace (510 ton $/ \mathrm{d} \mathrm{O}_{2}$ for each $10^{6}$ ton/yr blast furnace).

since both of these areas present advantages which would more than offset the cost of oxygen enrichment.

(3) Oxygen enrichment does not appear to have a potential market in

Coal gasification

Fuel cell power generation 
since neither of these areas presents sufficient advantages to offset the oxygen enrichment costs.

(4) There appears to be a slight, but possibly significant advantage for vacuum operation over pressure operation.

(5) There is no significant difference in oxygen enrichment for the three flow modes that could be used in a diffusion cell. These flow modes refer to the permeate and residue being in

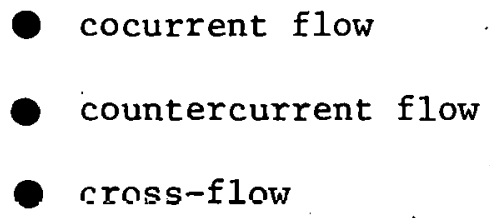

\section{Recommendationc}

(1) Develop membranes with higher permeability ratios. The higher the ratio the higher can be the oxygen content, or the higher can be the yield and lower can be the cost at the same oxygen content.

(2) Develop a more definitive analysis of the potential of using oxygen enrichment in MHD and in blast furnaces. Stress should be given. to the latter since this is more immediately possible, and a detailed analysis will be needed here to push a historically conservative industry in this direction. Such an analysis should be aimed both at retrofitting old furnaces and at new modern furnaces (which the U.S. sorely needs). A detailed analysis of the furnace temperature profile is needed, together with an analysis of means for recovering the available energy previously used in the air preheater.

(3) Uptimize the membrane diffusion system so as to select the most economic combination of process conditions. The conditions to be considered are: pressure ratio, vacuum vs. pressure operation, percent recovery, and permeability coefficients and ratio.

(4) Develop a detailed membrane cell design applicable to handling gases, and test the performance of such a design under expected conditions.

\section{RFFERENCES}

1. K. Kammermeyer, Silicone Rubber as a Selective Barrier. Ind. Eng. Chem. 49, 1685 (1957).

2. W. L. Robb, Thin Silicone Membranes--Their Permeation Properties and some Applications, Ann. N:Y. Acad. Sci. 146, 119 (1967). 
APPENDIX A

PRELIMINARY ANALYSIS OF MEMBRANE OXYGEN ENRICHMENT ECONOMICS*

*Prepared by Lowe11 J. Burnett, Fluid Systems Division, Basic Development Department, UIOP Inc. 
TABLE OF CONTENTS

\section{$\underline{\text { Page }}$}

I. INTRODUCTION ...................... 13

II. CONCLUSION . . . . . . . . . . . . . . . . 13

III. ECONOMIC COMPARISON . . . . . . . . . . . . . 15

A. System Parameters ................ 16

B. Capital Investment Required for Oxygen Production . . . 18

c. Energy Required for Oxygen Production . . . . . . . 22

D. Total Estimated Cost for Oxygen Production . . . . . 22

REFERENCES . . . . . . . . . . . . . . . . . . . . 28 


\section{PRELIMINARY ANALYSIS OF MEMBRANE OXYGEN ENRICHMENT ECONOMICS}

by

Lowe11 J. Burnett*

\section{INTRODUCTION}

An economic comparison between a proposed membrane process for production of oxygen-enriched air and the traditional cryogenic and pressure swing ahsorptinn methods is outlined here. In Llie proposed process an ultrathin polymer film, which is more permeable to oxygen than to nitrogen, will be used to separate the air passing over its surface into an oxygen-enriched stream (passing through the membrane) and an oxygen-depleted or nitrogenenriched stream (exiting at the downstream on the membrane surface). There are at least three important parameters of this membrane separation process: the membrane permeability, the membrane selectivity, and the pressure difference across the membrane, $i . e .$, the transmembrane pressure.

Comparisons of proposed processes with well-established existing processes are sometimes difficult and often dangerous. In the absence of pilot-plant data on a modest scale, these comparisons are often optimistic and tend to present the proposed process in the best possible light. However, to estimate the projected costs for oxygen enrichment using thin-film membranes, and to compare these to the well-known costs for oxygen enrichment via cryogenic technology, does not require the range of assumptions normally found in this type of study. This circumstance is due to the previous development and commercialization of thin-film membrane systems for the purification of both brackish water and seawater. Membranes of similar complexity to those in the proposed process are currently in production, and the associated system costs can be accurately estimated. Therefore, industry-wide experience with membrane separation of aqueous feed provides a broad and accurate data base from which to draw.

Cost comparisons of membrane and cryogenic oxygen enrichment can be made in at least three ways: by comparison of the capital investment required per ton of equivalent pure oxygen produced; by comparison of the energy required per equivalent ton of pure oxygen; and by comparison of the total estimated costs for an equivalent ton of pure oxygen. Comparisons based on each of these three methods, as functions of the three important membrane separation parameters, are presented in Section III.

\section{CONCLUSION}

A membrane process for the production of oxygen-enriched air has been evaluated as a function of membrane selectivity, membrane permeability, and transmembrane pressure. Process economics were evaluated in terms of the capital investment required for implementation, the energy required to operate the process, and the total estimated cost of the product oxygen.

*Fluid Systems Division, Basic Development Department, UOP, Inc. 
A summary of the findings is given in Fig. A-1. This is a plot of oxygen cost, in dollars/ton, versus oxygen consumption, in ton/d, for the three existing methods of delivery and for the proposed membrane enrichment process operated under four distinct conditions. The three common methods of delivery are: (a) delivered liquid oxygen (LOX) for consumption rates up to about 4 ton/d; (b) on-site production using pressure swing absorption (PSA) for rates up to about $40 \mathrm{ton} / \mathrm{d}$; and (c) on-site cryogenic production of gaseous oxygen (GOX) at rates greater than about 40 ton/d. Each of these methods produces essentially pure, i.e., 100\% oxygen.

Four membrane enrichment processes were examined: (a) production of $35 \%$ oxygen using a membrane with an oxygen-nitrogen selectivity of 2.2 and a transmembrane pressure of $0.9 \mathrm{~atm}$; (b) production of $30 \%$ oxygen using the same membrane as in (a) operated at a pressure difference of 0.7 atm; (c) production of $50 \%$ oxygen using a membrane with an oxygen-nitrogen selectivity of 4.5 and a transmembranc pressure of 0.9 atm; and, (d) production of $40 \%$ oxygen using the same membrane as in (c) opcrated at a pressure difference of $0.7 \mathrm{~atm}$. For these partially-enriched products, costs were calculated in terms of equivalent tons of pure uxygen. That is, one ton of equivalent oxygen corresponds to the (much larger) amount of partiallyenriched product which could be produced by missing that Luis of prire oxygen with normal air.

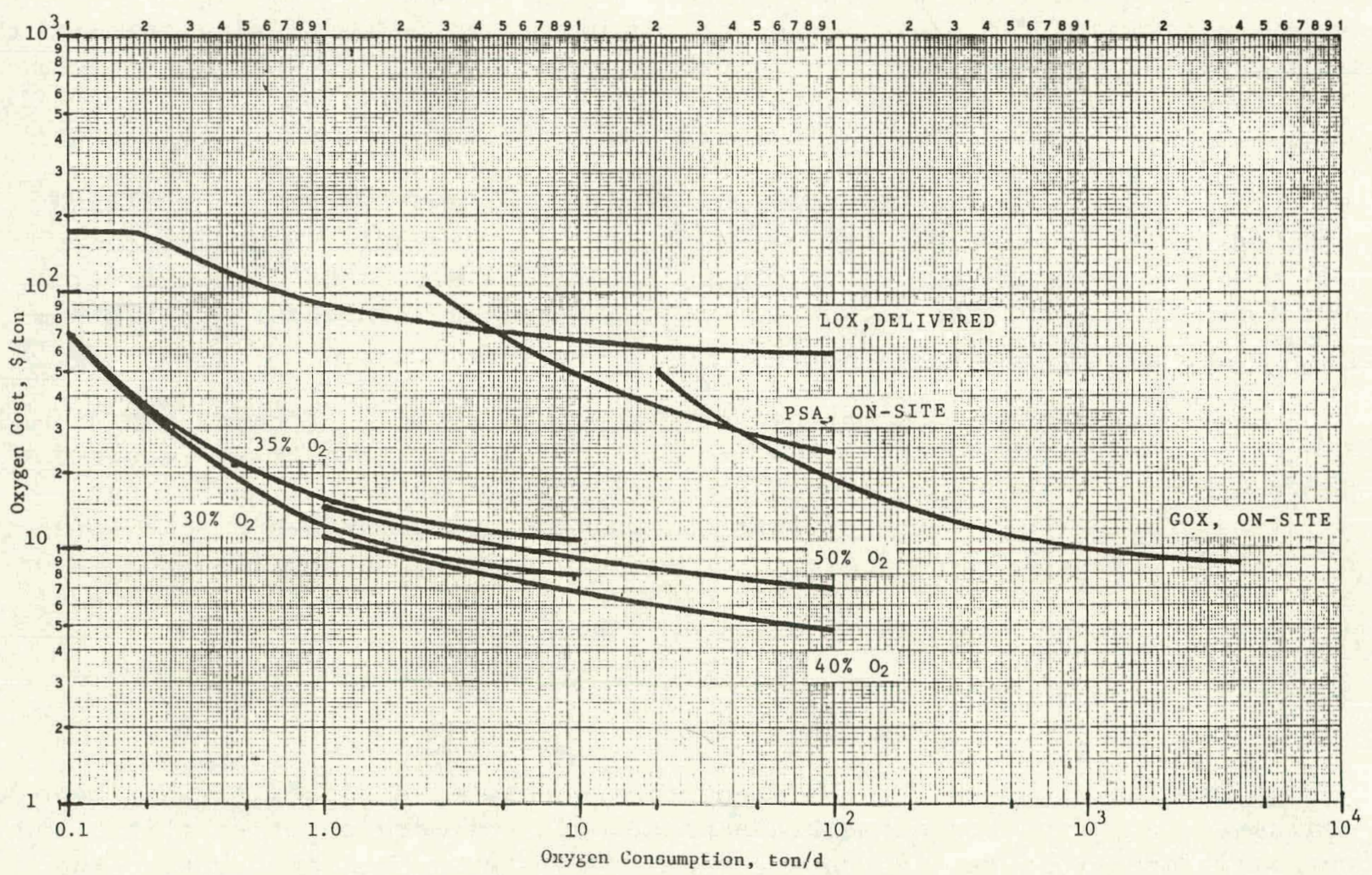

Fig. A-1. Oxygen Cost Versus Consumption Rate 
As shown in Fig. A-l, the estimated total cost of oxygen-enriched air is significantly less for the membrane enrichment processes. Furthermore, the projected costs decrease with increasing membrane selectivity, a condition that also provides a more highly enriched product. Product cost appears to fall as the transmembrane pressure is lowered, though estimates were made only over a narrow range of operating conditions. However, reduction of the pressure difference across the membrane leads to a more dilute product, thus limiting its utility. As expected, an increase in membrane permeability also decreases the estimated cost of the product.

\section{ECONOMIC COMPARISON}

At present, for oxygen consumption rates of less than about 4 ton/d, it is most economical to have liquid oxygen (LOX) delivered to storage facilities at the site. At higher levels, up to about 40 ton/d, oxygen generated on-site by pressure swing absorption (PAS) is most economical. Above 40 to $50 \mathrm{ton} / \mathrm{d}$, it becomes more economical to generate gaseous oxygen (GOX) on-site with a cryogenic facility. A plot of oxygen cost versus consumption rate ${ }^{1,2}$ for these three methods of oxygen delivery is shown in Fig. A-1. At low consumption levels, these numbers include the estimated costs of LOX storage facilities.

These methods of oxygen production provide an essentially pure gaseous product, i.e., 100\% oxygen. It is likely, however, that many processes could be improved through the utilization of air which is low or moderately enriched in oxygen. For this reason, the cost of oxygen-enriched air has been calculated for the membrane enrichment process operating under four separate conditions. In each case the basis for comparison is the equivalent pure oxygen production rate, $i . e$. ; the amount of pure oxygen that would have to be produced and mixed with normal air in order to provide the oxygen percentage indicated for the product in each process.

The first two membrane enrichment processes considered assume a $500-\AA$ ultrathin barrier formulated from a dimethyl silicone polymer. This polymer has a high oxygen permeability and has an oxygen-nitrogen separation factor $\alpha\left(0_{2} / \mathrm{N}_{2}\right)$ of approximately 2.2 . When this membrane is operated at a pressure difference of $0.9 \mathrm{~atm}$, with normal atmospheric pressure on the feed side of the membrane and $0.1 \mathrm{~atm}$ on the low pressure side, the enriched product stream contains $35 \%$ oxygen. If this same membrane is operated with a transmembrane pressure of $0.7 \mathrm{~atm}$, i.e., $1.0 \mathrm{~atm}$ on the feed side and $0.3 \mathrm{~atm}$ on the permeate side, the membrane provides a product enriched to $30 \%$ oxygen. 


\section{A. System Parameters}

Preliminary parameters used in the system design for these two operating conditions are shown in Tables $A-1$ and $A-2$. The first two columns show the product flow rate in standard cubic feet per minute, scfm, as a function of equivalent oxygen production in ton/d. The third column specifies both the number and size of the spiral-wound elements required to achieve this level of production. Spiral-wound Elements A-D are currently in production for seawater desalination applications, and Element Type $E$ is projected to be in production soon. In addition, it should be noted that even at extremely high levels of oxygen production, the projected number of spiral elements in a system remains manageable and is, in fact, less than that found in many water-treatment systems.

The other two membrane-enrichment processes studied assume a $500-\AA$ membrane with a lower intrinsic oxygen permeability but a somewhat higher separation factor. The oxygen permeability assumed for these two cases was typical of polybutadiene, which has an oxygen permeability about one-fourth that of dimethyl silicone. The oxygen-nitrogen separation factor for this compound was assumed to be 4.5, comparable to measured separation factors for similar polymers. The first case, outlined in Table A-3, assumes a transmembrane pressure of $0.9 \mathrm{~atm}$ and results in a product of $50 \%$ oxygen. The number of spiral-wound elements required for this case remains manageable, even with the decreased membrane permeability, due in part to the reduced product flow rate. Table A-4 outlines the results expected for the same membrane operated at a transmembrane pressure of $0.7 \mathrm{~atm}$, resulting in a product of $40 \%$ oxygen.

Table A-1. System Parameters for 35\% 0xygen Product, $\alpha\left(\mathrm{O}_{2} / \mathrm{N}_{2}\right)=2.2, \Delta \mathrm{P}=0.9 \mathrm{~atm}$

\begin{tabular}{ccc}
$\begin{array}{c}\text { Equivalent } \mathrm{O}_{2} \\
\begin{array}{c}\text { Production, } \\
\text { ton/d }\end{array}\end{array}$ & $\begin{array}{c}\text { Product } \\
\text { Flow Rate, } \\
\text { scfm }\end{array}$ & $\begin{array}{c}\text { Number and } \\
\text { Type of } \\
\text { Elements }\end{array}$ \\
\hline 0.1 & 9.4 & $1, \mathrm{~A}$ \\
0.3 & 28.2 & $1, \mathrm{~B}$ \\
1.0 & 94 & $1, \mathrm{C}$ \\
10 & 940 & $3, \mathrm{D}$ \\
100 & 9,400 & $10, \mathrm{E}$ \\
1000 & 94,000 & $100, \mathrm{E}$
\end{tabular}

Element type: A, $20 \mathrm{ft}^{2}$ in $2.5 \times 40 \mathrm{in}$.

$\mathrm{B}, 65 \mathrm{ft}^{2}$ in $4 \times 40$ in.

C, $165 \mathrm{ft}^{2}$ in $6 \times 40 \mathrm{in}$.

$\mathrm{D}, 360 \mathrm{ft}^{2}$ in $8 \times 40 \mathrm{in.}$

E. $910 \mathrm{ft}^{2}$ in $12 \times 40$ in: 
Table A-2. System Parameters for 30\% Oxygen Product, $\alpha\left(0_{2} / \mathrm{N}_{2}\right)=2.2$, $\Delta \mathrm{P}=0.7 \mathrm{~atm}$

\begin{tabular}{ccc}
\hline $\begin{array}{c}\text { Equivalent } \mathrm{O}_{2} \\
\text { Production, } \\
\text { ton/d }\end{array}$ & $\begin{array}{c}\text { Product } \\
\text { F1ow Rate, } \\
\text { scfm }\end{array}$ & $\begin{array}{c}\text { Number and } \\
\text { Type of } \\
\text { Elements }\end{array}$ \\
\hline 0.1 & 14.6 & $\begin{array}{l}1, \mathrm{~A} \\
1, \mathrm{~B}\end{array}$ \\
0.3 & $\begin{array}{c}13.8 \\
1, \mathrm{C}\end{array}$ \\
1.0 & 1,460 & $2, \mathrm{E}$ \\
10 & 14,600 & $16, \mathrm{E}$ \\
100 & 146,000 & $160, \mathrm{E}$ \\
& & \\
Element Type: & A, $20 \mathrm{ft}^{2}$ in $2.5 \times 40 \mathrm{in}$. \\
& B, $65 \mathrm{ft}^{2}$ in $4 \times 40$ in. \\
& C, $165 \mathrm{ft}^{2}$ in $6 \times 40$ in. \\
& D, $360 \mathrm{ft}^{2}$ in $8 \times 40$ in. \\
& E, $910 \mathrm{ft}^{2}$ in $12 \times 40$ in. \\
\hline
\end{tabular}

Table A-3. System Parameters for. 50\% Oxygen Product, $\alpha\left(\mathrm{O}_{2} / \mathrm{N}_{2}\right)=4.5$, $\Delta \mathrm{P}=0.9 \mathrm{~atm}$

\begin{tabular}{|c|c|c|c|}
\hline $\begin{array}{c}\text { Equivalent } 0 . \\
\text { Production, } \\
\text { ton } / \mathrm{d}\end{array}$ & & $\begin{array}{c}\text { Product } \\
\text { Flow. Rate, } \\
\text { scfm }\end{array}$ & $\begin{array}{l}\text { Number and } \\
\text { Type of } \\
\text { Elements }\end{array}$ \\
\hline $\begin{array}{r}0.1 \\
0.3 \\
1.0 \\
10 \\
100 \\
1000\end{array}$ & & $\begin{array}{r}4.5 \\
13.6 \\
45.3 \\
453 \\
4,530 \\
45,300\end{array}$ & $\begin{array}{r}1, \mathrm{~B} \\
1, \mathrm{C} \\
1, \mathrm{D} \\
5, \mathrm{E} \\
43, \mathrm{E} \\
430, \mathrm{E}\end{array}$ \\
\hline Element & Type: & \multicolumn{2}{|c|}{$\begin{array}{l}\mathrm{A}, 20 \mathrm{ft}^{2} \text { in } 2.5 \times 40 \mathrm{in} . \\
\mathrm{B}, 65 \mathrm{ft}^{2} \text { in } 4 \times 40 \mathrm{in} . \\
\mathrm{C}, 165 \mathrm{ft}^{2} \text { in } 6 \times 40 \mathrm{in} . \\
\mathrm{D}, 360 \mathrm{ft}^{2} \text { in } 8 \times 40 \mathrm{in.} \\
\mathrm{E}, 910 \mathrm{ft}^{2} \text { in } 12 \times 40 \text { in. }\end{array}$} \\
\hline
\end{tabular}


Tatle A-4. System Parameters for $40 \%$ Oxygen

Product, $\alpha\left(\mathrm{O}_{2} / \mathrm{N}_{2}\right)=2.2$, $\Delta \mathrm{P}=0.7 \mathrm{~atm}$

\begin{tabular}{ccc}
\hline $\begin{array}{c}\text { Equivalent } \mathrm{O}_{2} \\
\text { Production, } \\
\text { ton/d }\end{array}$ & $\begin{array}{c}\text { Product } \\
\text { Flow Rate, } \\
\text { scfm }\end{array}$ & $\begin{array}{c}\text { Number and } \\
\text { Type of } \\
\text { Elements }\end{array}$ \\
\hline 0.1 & 6.9 & 1, B \\
0.3 & 20.8 & $1, \mathrm{D}$ \\
1.0 & 69.3 & $1, \mathrm{E}$ \\
10 & 693 & $8, \mathrm{E}$ \\
100 & 6,930 & $80, \mathrm{E}$ \\
1000 & 69,300 & $800, \mathrm{E}$
\end{tabular}

Element Type: A, $20 \mathrm{ft}^{2}$ in $2.5 \times 40 \mathrm{in}$.

$\mathrm{B}, 65 \mathrm{ft}^{2}$ in $4 \times 40$ in.

r., $165 \mathrm{ft} 2$ in $6 \times 4 n$ in.

$\mathrm{D}, 360 \mathrm{ft}^{2}$ in $8 \times 40 \mathrm{in}$.

$\mathrm{E}, 910 \mathrm{ft}^{2}$ in $12 \times 40 \mathrm{in}$.

\section{B. Capital Investment Required for Oxygen Production}

Cryogenic oxygen facilities have been constructed with a wide range of product delivery rates, as summarized in Fig. A-1, and the capital costs required for typical installations are well known. Table A-5 details the capital investment required* for on-site cryogenic oxygen facilities in the production range of 100-2,000 ton/d.

Capital costs range from $\$ 2$ million to $\$ 26$ million, and the capital cost per ton of production capacity falls from $\$ 20,000$ per ton/d for modest production levels to a low of $\$ 13,000 \mathrm{per}$ ton $/ \mathrm{d}$ at the highest production levels.

The corresponding capital investments required for membrane oxygen enrichment, under each of the operating conditions outlined above, are detailed in the next four tables. Table A-6 shows the capital investment required for a membrane oxygen enrichment facility producing $35 \%$ oxygen, i.e., employing a membrane with an oxygen-nitrogen separation factor of 2.2 and operated with a transmembrane pressure of $0.9 \mathrm{~atm}$. The capital costs have been estimated for equivalent oxygen production rates ranging from 0.1 ton $/ \mathrm{d}$ to $1,000 \mathrm{ton} / \mathrm{d}$. Membrane costs have been estimated from the system design data, presented in Table A-1, using the current retail price for spiral-wound elements that incorporate a seawater desalination membrane of similar complexity to that of the proposed gas membrane.

*Although these numbers were supplied to us by American Liquide', the corporation that constructed the three 2,000-ton/d oxygen plants for the South African SASOL coal gasification project, they are in close agreement with costs supplied us by other producers of cryogenic oxygen plants. 
Table A-5. Capital Investment Required

for an On-Site Cryogenic

Oxygen Facility

\begin{tabular}{ccc}
\hline $\begin{array}{c}\text { Equivalent } 0_{2} \\
\begin{array}{c}\text { Production, } \\
\text { ton/d }\end{array}\end{array}$ & $\begin{array}{c}\text { Capital } \\
\text { Cost, } \\
\$\end{array}$ & $\begin{array}{c}\text { Capital } \\
\text { Cost }, \\
\$ /(\text { ton/d) }\end{array}$ \\
\hline 100 & $2 \times 10^{6}$ & 20,000 \\
500 & $8 \times 10^{6}$ & 16,000 \\
1000 & $14 \times 10^{6}$ & 14,000 \\
2000 & $26 \times 10^{6}$ & 13,000 \\
\hline
\end{tabular}

Pump costs were obtained from a cross section of American pump manufacturers and, as outlined in greater detail in the section on total costs, generally involve rotary vane pumps at low production rates, and liquid ring pumps at the higher production rates. Pump costs for production levels greater than 10 ton/d of equivalent pure oxygen were not tabulated due to the difficulty in obtaining reliable estimates from manufacturers. It should be clear, however, that pump prices for the higher production rates, i.e., 100 and 1,000 ton/d, cannot rise above the 10 -ton/d value.

The system costs include the estimated cost of pressure vessels, piping, flow and composition instrumentation, and a base with framing. From the final column in Table A-6, it is obvious that the total capital investment required falls dramatically as a function of increased oxygen production. At a level of 10-ton/d equivalent oxygen production, the capital investment required has fallen to less than $\$ 13,000$ per ton/d, a figure comparable to that of the highest capacity cryogenic oxygen facilities.

A significant decrease in the capital investment required for membrane oxygen production is obtained by reducing the transmembrane pressure to 0.7 atm. This is illustrated in Table A-7, which details capital investment for a membrane oxygen enrichment facility producing a $30 \%$ oxygen product. This reduction in capital investment approaches $45 \%$ at the higher production rates and is due mainly to increased pumping efficiency at these operating pressures.

Across-the-board reduction in the capital investment required is obtained by increasing membrane selectivity. Table A-8 detalls the capital necessary to construct a membrane oxygen-enrichment facility producing $50 \%$ oxygen using a membrane with an oxygen-nitrogen selectivity of 4.5 and a transmembrane pressure of $0.9 \mathrm{~atm}$. The reduction in product volume to be pumped provides most of the saving, and results in a projected capital investment of approximately $\$ 6,600$ per ton/d of capacity at a production level of $100 \mathrm{ton} / \mathrm{d}$. Again, reliable estimates of pump costs could not he made for production levels above this value. 
Table A-6. Capital Investment Required for a Membrane Oxygen Enrichment Facility, $35 \% \mathrm{O}_{2}$ Product, $\alpha\left(\mathrm{O}_{2} / \mathrm{N}_{2}\right)=2.2$, $\Delta \mathrm{P}=0.9 \mathrm{~atm}$

\begin{tabular}{ccccc}
\hline $\begin{array}{c}\text { Equivalent } 0_{2} \\
\text { Production, } \\
\text { ton/d }\end{array}$ & $\begin{array}{c}\text { Membrane } \\
\text { Cost, } \\
\$ /(\text { ton/d) }\end{array}$ & $\begin{array}{c}\text { Pump } \\
\text { Cost, } \\
\$ /(\text { ton/d) }\end{array}$ & $\begin{array}{c}\text { System } \\
\text { Cost, } \\
\$ /(\text { ton/d) }\end{array}$ & $\begin{array}{c}\text { Capital } \\
\text { Investment } \\
\$ /(\text { ton } / \mathrm{d})\end{array}$ \\
\hline 0.1 & 3,000 & 37,500 & 40,000 & 80,500 \\
0.3 & 1,800 & 15,330 & 15,000 & 32,130 \\
1.0 & 1,000 & 11,480 & 5,000 & 17,480 \\
10 & 330 & 10,920 & 1,500 & 12,750 \\
100 & 140 & & 450 & \\
1,000 & 140 & & 400 & \\
\hline
\end{tabular}

Table A-7. Capital Investment Required for a Membrane Oxygen Enrichment Facility, $30 \% \mathrm{O}_{2}$ Product, $\alpha\left(\mathrm{O}_{2} / \mathrm{N}_{2}\right)=2.2$, $\Delta \mathrm{P}=0.7 \mathrm{~atm}$

\begin{tabular}{ccccc}
\hline $\begin{array}{c}\text { Equivalent } 0_{2} \\
\text { Production, } \\
\text { ton/d }\end{array}$ & $\begin{array}{c}\text { Membrane } \\
\text { Cost, } \\
\$ /(\text { ton/d) }\end{array}$ & $\begin{array}{c}\text { Pump } \\
\text { Cost }, \\
\$ /(\text { ton } / d)\end{array}$ & $\begin{array}{c}\text { System } \\
\text { Cost }, \\
\$ /(\text { ton } / d)\end{array}$ & $\begin{array}{c}\text { Capital } \\
\text { Cost }, \\
\$ /(\text { ton } / d)\end{array}$ \\
\hline 0.1 & 3,000 & 9,000 & 40,000 & 52,000 \\
0.3 & 1,800 & 6,830 & 15,000 & 23,630 \\
1.0 & 1,000 & 5,950 & 5,000 & 11,950 \\
10 & 280 & 5,650 & 1,000 & 6,930 \\
100 & 220 & & 800 & \\
1,000 & 220 & & 720 & \\
\hline
\end{tabular}


Table A-8. Capita1 Investment Required for a Membrane Oxygen Enrichment Fac1lity, $50 \% 0_{2}$ Product, $\alpha\left(0_{2} / \mathrm{N}_{2}\right)=4.5$, $\Delta \mathrm{P}=0.9 \mathrm{~atm}$

\begin{tabular}{ccccc}
\hline $\begin{array}{c}\text { Equivalent } 0_{2} \\
\text { Production, } \\
\text { ton/d }\end{array}$ & $\begin{array}{c}\text { Membrane } \\
\text { Cost } \\
\$ /(\text { ton/d) }\end{array}$ & $\begin{array}{c}\text { Pump } \\
\text { Cost }, \\
\$ /(\text { ton } / d)\end{array}$ & $\begin{array}{c}\text { System } \\
\text { Cost }, \\
\$ /(\text { ton/d })\end{array}$ & $\begin{array}{c}\text { Capital } \\
\text { Cost }, \\
\$ /(\text { ton/d })\end{array}$ \\
\hline 0.1 & 5,400 & 8,000 & 45,000 & 58,000 \\
0.3 & 3,330 & 6,000 & 16,670 & 26,000 \\
1.0 & 1,100 & 5,300 & 5,500 & 11,900 \\
10 & 700 & 5,270 & 2,000 & 7,970 \\
100 & 600 & 5,030 & 1,000 & 6,630 \\
1,000 & 600 & & 900 & \\
\hline
\end{tabular}

If this membrane is now operated at a pressure difference of $0.7 \mathrm{~atm}$, providing a product stream of $40 \%$ oxygen, the capital investment required falls to an even lower value, as shown in Table A-9. At a 100-ton/d production level, the capital investment required is estimated to be less than $\$ 5,200$ per ton/d, approximately $25 \%$ of that required for a cryogenic oxygen facility of the same size. It should be noted that these capital investment figures were calculated for the specific equipment required to operate at the lowest overall cost, as discussed later, and this basis for comparison leads to the fluctuations observed in the low production level estimates.

Table A-9. Capital Investment Required for a Membrane Oxygen Enrichment Facility, $40 \% \mathrm{O}_{2}$ Product, $\alpha\left(\mathrm{O}_{2} / \mathrm{N}_{2}\right)=4.5$, $\Delta \mathrm{P}=0.7 \mathrm{~atm}$

\begin{tabular}{ccccc}
\hline $\begin{array}{c}\text { Equivalent } 0_{2} \\
\text { Production, } \\
\text { ton/d }\end{array}$ & $\begin{array}{c}\text { Memhrane } \\
\text { Cost } \\
\$ /(\text { ton/d) }\end{array}$ & $\begin{array}{c}\text { Pump } \\
\text { Cost }, \\
\$ /(\text { ton/d) }\end{array}$ & $\begin{array}{c}\text { System } \\
\text { Cost }, \\
\$ /(\text { ton } / d)\end{array}$ & $\begin{array}{c}\text { Capital } \\
\text { Cost }, \\
\$ /(\text { ton } / \mathrm{d})\end{array}$ \\
\hline 0.1 & 5,400 & 12,000 & 45,000 & 62,400 \\
0.3 & 3,670 & 4,670 & 18,330 & 26,670 \\
1.0 & 1,400 & 3,550 & 6,000 & 10,950 \\
10 & 1,120 & 2,800 & 2,500 & 6,420 \\
100 & 1,120 & 2,570 & 1,500 & 5,190 \\
1,000 & 1,120 & & 1,350 & \\
\hline
\end{tabular}




\section{Power Required.for Oxygen Production}

It is well known that moderate- to large-scale cryogenic oxygen production requires between 18 and 18.5 brake HP per ton/d of production capactty. ${ }^{2}$ Based upon the information provided by pump manufacturers, power requirements for the membrane separation process were estimated and these results are tabulated in Table A-10. This table details process power consumption as a function of product oxygen composition at a constant production level of 1 ton/d. It is assumed that the oxygen-enriched product is produced as outlined in the previous section; $i . e$., the $30 \%$ and $35 \%$ oxygen products are produced by a membrane with an oxygen-nitrogen separation factor of 2.2 , while the $40 \%$ and $50 \%$ oxygen products are produced by a membrane with a separation factor of 4.5 .

From this table it can be seen that a significant reduction in the power requirement is ashieved when the membralie system is operated to produce a product of less than its maximum enrichment, i.e., $30 \%$ oxygen for the luw selectivity membrane and 40\% oxygen for the high selectivity membrane. In fact, for product air enriched to $40 \%$ bxygen, the estinated energy required falls to less than half of that necessary for a cryogenic oxygen separation. This is not surprising, however, because as the membrane selectivity is increased, the energy required for the oxygen-nitrogen separation process falls to its thermodynamic mimimum. This can be contracted to the cryogenic separation process in which the system must be taken irreversibly through a phase transition, then back again.

\section{Total Estimated Cost for Oxygen Production}

As shown in Fig. A-1, the cost of oxygen falls monotonically with increasing consumption; though at the highest production levels, fluctuations in energy cost, siting costs and labor rates introduce some

Table A-10. Power Required at a 1-(ton/d)

Production Level as a Function of Product Oxygen Composition

\begin{tabular}{cc}
$\begin{array}{c}\text { Product } \\
\begin{array}{c}\text { Composition, } \\
\% 0_{2}\end{array}\end{array}$ & $\begin{array}{c}\text { Power } \\
\text { Required, } \\
\text { Brake HP }\end{array}$ \\
\hline 30 & 10.9 \\
35 & 20.5 \\
40 & 8.0 \\
50 & 17.0 \\
\hline
\end{tabular}


uncertainties about the average values plotted. As a calibration point, however, it should be noted that at $\$ 2.5 / 10^{6} \mathrm{Btu}$, direct energy costs for a cryogenic plant (requiring 18.5 brake HP/ton of capacity) are $\$ 2.83 /$ ton .

Table A-11 details the total estimated cost per ton, at various production levels, for a membrane enrichment to $35 \%$ oxygen using a membrane with an oxygen-nitrogen separation factor of 2.2 and a transmembrane pressure of $0.9 \mathrm{~atm}$. The membrane cost was calculated from the retail price, as indicated previously, by assuming a membrane lifetime of 5 years. This estimate is probably somewhat conservative since the membrane is inert to all components of normal air and the membrane in the spiral-element configuration can be readily cleaned, if necessary. Pump prices were obtained Fur two distinct cypes of rotary vane oil seal pumps, steel vane models (SV) and composition vane models (CV), and for liquid ring (LR) pumps at higher production levels. Pump cost per ton of production capacity was then estimated assuming a pump lifetime of 10 years.

The system cost was then estimated using the data in Table A-6 to A-9 and assuming a system lifetime of 10 years. Energy costs were calculated from data supplied by pump manufacturers assuming a base rate of $\$ 2.5 / 10^{6} \mathrm{Btu}$, and estimates of labor and maintenance costs for both the pump and the system. are tabulated. These figures are based in part on our experience with smallscale gas membrane separation systems.

These individual costs are sumed to give the total projected cost shown in the final column. These costs fall to quite low values at moderate production levels. As indicated previously, estimates for production levels greater than approximately 10 ton/d equivalent pure oxygen were difficult to make due to the unreliability of pump cost figures.

Table A-12 details the total estimated cost per ton for $30 \%$ oxygen produced by operating the membrane in the previous example at a transmembrane pressure of $0.1 \mathrm{~atm}$. As we saw previously, the capital investment and the process energy requirement fell significantly under these operating conditions, and the same is true for the total estimated oxygen cost. At the modest level of 10 ton/d equivalent pure oxygen, the total cost per ton is project to be less than that of even very large scale cryogenic production.

Table A-13 details the total estimated cost per ton for 50\% oxygen produced by a membrane with an oxygen-nitrogen separation factor of 4.5 and operated at a transmembrane pressure of $0.9 \mathrm{~atm}$. Reliable estimates at higher production levels can be obtained in this case due to the reduction in product volume. The effects of reducing the transmembrane pressure to $0.7 \mathrm{~atm}$. are detailed in Table A-14, and result in a product of $40 \%$ oxygen. Again the increase in pumping efficiency results in a further decrease in projected costs, with the total estimated cost falling to less than $\$ 5 /$ ton at a level of $100 \mathrm{ton} / \mathrm{d}$ equivalent oxygen production. 
Table A-11. Total Estimated Cost Per Equivalent Ton for $35 \% 0_{2}$ Product, $a\left(0_{2} / \mathrm{N}_{2}\right)=2.2, \Delta \mathrm{P}=0.9 \mathrm{~atm}$

\begin{tabular}{|c|c|c|c|c|c|c|}
\hline $\begin{array}{l}\text { Equivaient } 0_{2} \\
\text { Production, } \\
\text { ton } / \mathrm{d}\end{array}$ & $\begin{array}{c}\text { Membrane } \\
\text { Sost } \\
\$ / \text { ton }\end{array}$ & $\begin{array}{l}\text { Pump } \\
\text { Cost, } \\
\text { \$/ton }\end{array}$ & $\begin{array}{l}\text { Jystem } \\
\text { Cost, } \\
\text { \$iton }\end{array}$ & $\begin{array}{l}\text { Energy } \\
\text { Cost } \\
\$ / \text { ton }\end{array}$ & $\begin{array}{c}\text { Labor and } \\
\text { Maintenance Cost, } \\
\$ / \text { ton }\end{array}$ & $\begin{array}{l}\text { Total } \\
\text { Cost } \\
\$ / \text { ton }\end{array}$ \\
\hline 0.1 & 1.644 & $\begin{array}{r}10.214(\mathrm{SV}) \\
4.932(\mathrm{CV})\end{array}$ & 10.959 & $\begin{array}{l}3.060 \\
4.590\end{array}$ & $\begin{array}{l}42.857 \\
53.571\end{array}$ & $\begin{array}{l}68.734 \\
75.696\end{array}$ \\
\hline 0.3 & 0.986 & $4.201(\mathrm{CV})$ & 4.110 & 3.825 & 17.857 & 30.979 \\
\hline 1.0 & D. 548 & $\begin{array}{l}3.144(\mathrm{CV}) \\
5.220(\mathrm{SV}) \\
3.332(\mathrm{LR})\end{array}$ & 1.370 & $\begin{array}{r}3.236 \\
3.236 \\
10.787\end{array}$ & 6.429 & $\begin{array}{l}14.727 \\
16.803 \\
22.466\end{array}$ \\
\hline 10 & 0.181 & $\begin{array}{l}2.992(\mathrm{CV}) \\
2.877(\mathrm{LR})\end{array}$ & 0.411 & $\begin{array}{l}3.222 \\
9.486\end{array}$ & 4.286 & $\begin{array}{l}11.092 \\
17.241\end{array}$ \\
\hline 100 & 0.077 & & 0.123 & & & \\
\hline 1000 & 0.077 & . & 0.110 & & & \\
\hline
\end{tabular}


Table A-12. Total Estimated Cost Per Equivalent Ton for

$30 \% \quad 0_{2}$ Product, $\alpha\left(\mathrm{O}_{2} / \mathrm{N}_{2}\right)=2.2, \Delta \mathrm{P}=0.7 \mathrm{~atm}$

\begin{tabular}{|c|c|c|c|c|c|c|}
\hline $\begin{array}{l}\text { Equivalent } \mathrm{O}_{2} \\
\text { Production, } \\
\text { ton/d }\end{array}$ & $\begin{array}{l}\text { Membrane } \\
\text { Cost, } \\
\$ / \text { ton }\end{array}$ & $\begin{array}{l}\text { Pump } \\
\text { Cost, } \\
\$ / \text { ton }\end{array}$ & $\begin{array}{l}\text { System } \\
\text { Cost, } \\
\text { \$/ton }\end{array}$ & $\begin{array}{l}\text { Energy } \\
\text { Cost, } \\
\$ / \text { ton }\end{array}$ & $\begin{array}{c}\text { Labor and } \\
\text { Maintenance Cost, } \\
\$ / \text { ton }\end{array}$ & $\begin{array}{l}\text { Total } \\
\text { Cost } \\
\$ / \text { ton }\end{array}$ \\
\hline 0.1 & 1.644 & $2.466(\mathrm{CV})$ & 10.959 & 3.143 & 53.571 & 71.783 \\
\hline 0.3 & 0.986 & $1.872(\mathrm{CV})$ & 4.110 & 2.327 & $17 . .857$ & 27.152 \\
\hline . 1.0 & 0.548 & $\begin{array}{l}1.628(\mathrm{CV}) \\
2.703(\mathrm{SV}) \\
1.725(\mathrm{LR})\end{array}$ & 1.370 & $\begin{array}{l}1.67 .5 \\
1.675 \\
5.585\end{array}$ & 6.429 & $\begin{array}{l}11.650 \\
12.725 \\
15.657\end{array}$ \\
\hline 10 & 0.153 & $1.548(\mathrm{CV})$ & 0.274 & 1.668 & 4.286 & 7.929 \\
\hline 100 & 0.123 & r & 0.219 & & & \\
\hline 1000 & 0.123 & & 0.197 & & & \\
\hline
\end{tabular}


Table A-13. Total Estimated Cost Per Equivalent Ton for $50 \% \mathrm{D}_{2}$ Product, $\alpha\left(\mathrm{O}_{2} / \mathrm{N}_{2}\right)=4.5,{ }^{\mathrm{A}} \mathrm{P}=0.9 \mathrm{~atm}$

\begin{tabular}{|c|c|c|c|c|c|c|}
\hline $\begin{array}{c}\text { Equivalent } 0_{2} \\
\text { Production, } \\
\text { ton/d }\end{array}$ & $\begin{array}{l}\text { Membrane } \\
\text { Sost } \\
\text { \$/ton }\end{array}$ & $\begin{array}{l}\text { Pump } \\
\text { Cost } \\
\$ / \text { ton }\end{array}$ & $\begin{array}{l}\text { System } \\
\text { Cost, } \\
\text { \$iton }\end{array}$ & $\begin{array}{l}\text { Energy } \\
\text { Cost, } \\
\$ / \text { ton }\end{array}$ & $\begin{array}{c}\text { Labor and } \\
\text { Maintenance Cost, } \\
\$ ! \text { ton }\end{array}$ & $\begin{array}{l}\text { Total } \\
\text { Cost, } \\
\$ / \text { ton }\end{array}$ \\
\hline 0.1 & 2.959 & $2.192(\mathrm{CV})$ & 12.329 & 2.907 & 53.571 & 73.958 \\
\hline 0.3 & 1.826 & $1.644(\mathrm{CV})$ & 4.566 & 2.805 & 17.857 & 28.698 \\
\hline 1.0 & 0.603 & $1.452(\mathrm{CV})$ & 1.507 & 2.601 & 6.429 & 12.592 \\
\hline 10 & 0.384 & $1.443(\mathrm{CV})$ & 0.548 & 2.585 & 4.286 & .9 .246 \\
\hline 100 & 0.330 & $1.379(\mathrm{LR})$ & 0.274 & 4.313 & 0.857 & 7.153 \\
\hline 1000 & 0.330 & & & & & \\
\hline
\end{tabular}


Table A-14. Total Estimated Cost Per Equivalent Ton for $40 \% \mathrm{O}_{2}$ Product, $\alpha\left(0_{2} / \mathrm{N}_{2}\right)=4.5, \Delta \mathrm{P}=0.7 \mathrm{~atm}$

\begin{tabular}{|c|c|c|c|c|c|c|c|}
\hline $\begin{array}{c}\text { Equivalent } \mathrm{O}_{2} \\
\text { Producticn, } \\
\text { ton } / \mathrm{d}\end{array}$ & $\begin{array}{l}\text { Membrane } \\
\text { Cost, } \\
\text { \$/ton }\end{array}$ & & $\begin{array}{l}\text { Pump } \\
\text { Cost } \\
\text { \$/ton }\end{array}$ & $\begin{array}{l}\text { System } \\
\text { Cost, } \\
\text { S/ton }\end{array}$ & $\begin{array}{l}\text { Energy } \\
\text { Cost, } \\
\$ / \text { ton }\end{array}$ & $\begin{array}{c}\text { Labor and } \\
\text { Maintenance Cost } \\
\$ / \text { ton }\end{array}$ & $\begin{array}{l}\text { Total } \\
\text { Cost, } \\
\$ / \text { ton }\end{array}$ \\
\hline 0.1 & 2.959 & $\cdots$ & $3.288(\mathrm{CV})$ & 12.329 & 1.530 & 42.857 & 62.963 \\
\hline 0.3 & 2.009 & & $1.279(\mathrm{CV})$ & 5.023 & 1.530 & $17: 857$ & 27.698 \\
\hline 1.0 & 0.767 & $\ldots$ & $0.973(\mathrm{cV})$ & 1.644 & 1.224 & 6.429 & 11.037 \\
\hline 10 & 0.614 & & $0.767(\mathrm{CV})$ & 0.685 & 0.826 & 4.286 & 7.178 \\
\hline 100 & 0.614 & & $0.703(\mathrm{LR})$ & 0.411 & 2.199 & 0.857 & 4.784 \\
\hline 1000 & 0.614 & & & & & & \\
\hline
\end{tabular}




\section{REFERENCES}

1. W. J. Storck, Industrial Gases, Chem. Eng. News, p. 8, July 18, 1977.

2. B. D. Bracken, What's up with Oxygen?, Water Wastes Eng., March-April, 1977. 


\begin{abstract}
APPENDIX B
AN ENGINEERING STUDY TO EVALUATE COST OF MEMBRANE GAS SEPARATION PROCESSES*
\end{abstract}

for ANL under Contract No. 31-109-38-4540

September 1978

*Prepared by Econergy Associates, 799 Bruadway, New York, New York 10003 
'IABLE OF CONTENTS

$\underline{\text { Page }}$

I. OBJECTIVE .................... . . . . 31

II. SUMMARY . . . . . . . . . . . . . . . . . 31

III. CONCLUSIONS . . . . . . . . . . . . . . . . 32

IV. RECOMMENDATIONS ..................... . . . . 32

V. INTRODUCTION ..................... . . . . . 33

VI. PROCESS DESCRIPTION . . . . . . . . . . . . . . 32

A. Alternate Process Designs . . . . . . . . . . 34

B. Factors Afferting the Membranc Performance . . . . . 37

C. Membrane Cell Design . . . . . . . . . . . 37

VII. PROCESS ECONOMICS . . . . . . . . . . . . . . 38

A. Capital Costs . . . . . . . . . . . . . 38

B. Operating Costs ................ 39

C. Comparison with Cryogenic Air Separation . . . . . . 40

V̇III. PROCESS APPLICATIONS . . . . . . . . . . . . . 41

A. MHD ..................... . . . 41

B. Iron Blast Furnaces................ 42

C. Coal Gasification ................ . . 44

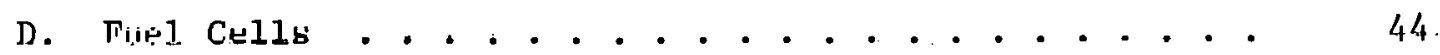

SUPPLEMENT

ANALYSIS UF FACiIORS AFFECTING MEMBRANE PERFORMANCE . . . • 
AN ENGINEERING STUDY TO EVALUATE COSTS OF
MEMBRANE GAS SEPARATION PROCESSES

by

Econergy Associates

I. OBJECTIVE

The objectives of this study are to

- evaluate the economics of producing enriched oxygen by the membrane diffusion process by

(1) extrapolating the process economics to large scale $\left(1000 \mathrm{TPD} 0_{2}\right.$ )

(2) Comparing the cost so derived with those for liquid air separation.

- identify potential areas where enriched oxygen could have a market, today or in the future.

- identify areas of desirable development work on the diffusion process.

\section{SUMMARY}

Background material from Fluid Systems Division of UOP and from Argonne National Laboratory was reviewed. From this an analysis was made of expected performance for a range of : permeate recoveries; pressure ratios (of permeate to feed); permeability ratios (permeability coefficient of oxygen through membrane divided by coefficient of nitrogen); and number. of diffusion stages.

Flow sheets were developed for pressure operation (teed air pressurized) and for vacuum operation (permeate removed under vacuum). These flow sheets presented: the key flow lines and equipment; the material and energy balances for producing 1000 TPD oxygen as $30 \% \mathrm{O}_{2}$; and performance specifications of the key equipment. Capital and operating costs were developed for these designs, and these were compared to those for oxygen enrichment using liquid air separation.

The market potential for oxygen-enriched air was analyzed for applications in: MHD power generation, iron blast furnaces, coal gasification, and fuel cell power generation. 


\section{CONCLUSIONS}

1. The membrane diffusion process is competitive with liquid air separation for producing oxygen-enriched air. The estimated capital advantage is 3.84.1 million dollars for $1000 \mathrm{TPD}$ oxygen as $30 \% \mathrm{O}_{2}$. The bottom-1ine cost advantage is $\$ 2.11$ to $\$ 3.68$ per ton $0_{2}$.

2. Oxygen enrichment has a potential market in

- MHD power generation (14000 TPD $0_{2}$ for $1000 \mathrm{MW}$ ).

- Iron blast furnace (510 TPD $0_{2}$ for each 1 MM TPY* blast furnace). since both of these areas present advantages which won1d more than offset the cost of oxygen enrichment.

3. Oxygen enrishment dnes not appoar to have a potential matket in

- Coal gasification

- Fuel cell power generation

since both of these areas to not present sufficient advantages to offset the oxygen-enrichment costs.

-4. There appears to be a slight, but possibly significant, advantage for vacuum operation over pressure operation.

5. There is no significant difference in oxygen enrichment for the three Hlow modes that could be used in a diffusion cell. These flow modes refer to the permeate and residue being in
- cocurrent
- countercurrent flow
- cross-flow

\section{RECOMMENDATIONS}

1. Develop membranes with higher permeability ratios. The higher the ratio the higher cal be the oxygen content, or the higher can be the yield and lower can be the cost at the same oxygen content.

2. Develop a more definitive analysis of the potential of using oxygen enrichment in MHD and in blast furnaces. Stress should be given to the latter since this is more immediately possible, and a detailed analysis will be needed here to push a historically conservative industry in this direction. Such an analysis should be aimed both at retrofitting old furnaces and at

*In this appendix, $M=10^{3}$ and $M M=10^{6}$. 
new modern furnaces (which the U.S. sorely needs). A detailed analysis of the furnace temperature profile is needed, together with an analysis of means for recovering the available energy previously used in the air preheater.

3. Optimize the membrane diffusion system so as to select the most economic combination of process conditions. The conditions to be considered are: pressure ratio, vacuum vs. pressure operation, percent recovery, and permeability coefficients and ratios.

4. Develop a detailed membrane cell design applicable to handling gases, and tcet the performance of such a design under expected conditions.

\section{INTRODUCTION}

The present engineering study resulted out of recent advances by the Fluid Systems Division of UOP, Inc. in the identification and testing of membranes for the separation of gas components in binary mixtures. Several of these membranes showed good component separability and adequately high gas diffusion flux capability. Based on these findings, Fluid systems has made preliminary estimates of the economics of producing oxygen-enriched air, comparing membrane diffusion with liquid air separation (see Appendix A). These estimates showed that the diffusion system offered potential savings over liquid air separation at low production $r$ ates.

This study extends the Fluid Systems work to large tonnage rates (1000 TPD), which would be encountered in potential commercial applications. Additionally, this study examines several potential commercial applications and evaluates the incentives for such applications.

\section{PROCESS DESCRIPTION}

The basic process for membrane separation of gases is based on a difference in the rate of diffusion of the different components in the feed gas. For the subject evaluation, the feed gas is air. Oxygen in the air diffuses more rapidly through the polymer membrane than nitrogen, and hence there will be a higher oxygen concentration in the gas that passes through the membrane (permeate) than in the feed air. The flow rate of each component in the feed through the film is given by

$$
P_{i}=\frac{K_{i} A \triangle P_{i}}{L}
$$


where

$$
\begin{aligned}
\mathrm{P}_{i} & =\text { moles of component } i \text { per unit time }(e \cdot g ., \text { seconds) } \\
\mathrm{K}_{i} & =\begin{array}{l}
\text { permeability of component } i \text { (in units consistent with those for } \\
\text { the other symbols) }
\end{array} \\
\mathrm{A} & =\text { membrane area. } \\
\mathrm{L} & =\text { membrane thickness } \\
\Delta \mathrm{P}_{\mathbf{i}} & =\begin{array}{l}
\text { difference in the partial pressure of component } i \text { across the } \\
\text { membrane }
\end{array}
\end{aligned}
$$

The prime options available in conducting this process are:
- Pressure vs. vacuum operation to deve1np the necessary $\Delta \mathrm{P}^{\prime} \mathrm{s}$
- Pressure ratio and percent recovery
- Number of diffusion stages

This study will be limited to moderate oxygen enrichment, and hence will not include the multistage option.

\section{A. Alternate Process Designs.}

Figure B-1 presents the process flow diagram for $1000-T P D 0_{2}$ in a $30 \%$ $\mathrm{O}_{2}$ product, using a vacuum downstream of the membrane. Figure $\mathrm{B}-2$ presents the pressure option for the same production.

The vacuum option is simple. Clean air is pumped into a manifold of diffusion cells at about $\perp$ psig, sufficient to overcome the pressure drop upstream of the membrane. The permeate gas is pumped out by vacuum pumps which will create a pressure ratio of 0.2 across the membrane. (The pressure ratio is equal to the pressure after the membrane divided by the pressure before the membrane.) About $20 \%$ of the feed air diffuses through the cell; chis is the permeate. The bal,ance is the residue, and this is rejected to the atmosphere.

The pressure option is more complicated. Here, the clean air is compressed to about 5.1 atm in a two-stage compressor with inter-cooling. The hot-compressed air after the second stage is heat interchanged with the residue gas from the diffusinn cell; this recovers some of the heat by the residue. The residue is then further heated to $1230^{\circ} \mathrm{F}$ by combustion of a clean fuel (e.g., oil) with some of the oxygen in the residue. The resulting hot gases are expanded through a turbine which develops the power to drive the air compressor. The compressed air after heat interchange with the exiting residue gas is further cooled to about $120^{\circ} \mathrm{F}$ in a watercooled exchanger, and then fed to the diffusion cell, where about $2 \%$ of the feed air diffuses through the membrane, producing $30 \% 0_{2}$ permeate at about 1 atm. The balance of the air (the residue) exits at about $5 \mathrm{~atm}$, and power is recovered therefrom to drive the air compressor as described above. 


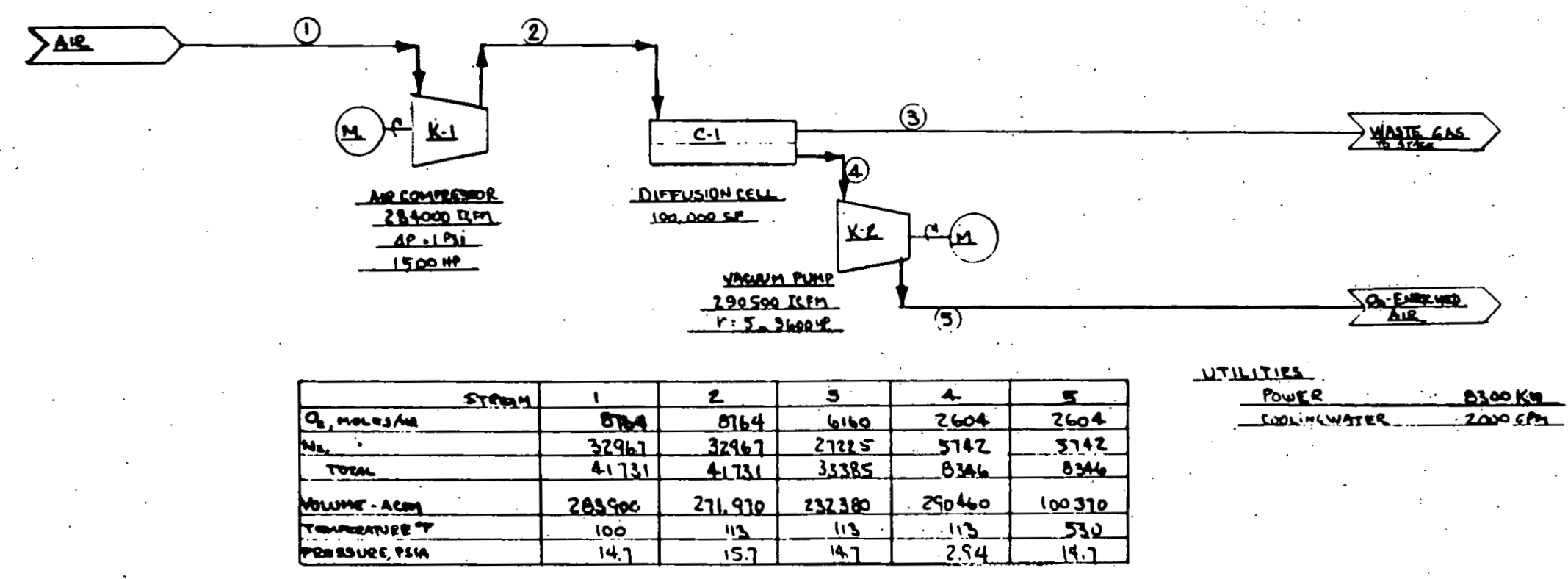

Fig. B-1. Process Flow Diagram for Vacuum Diffusion System (1000 TPD $\left.0_{2}, 30 \% 0_{2}\right): \ldots$ 


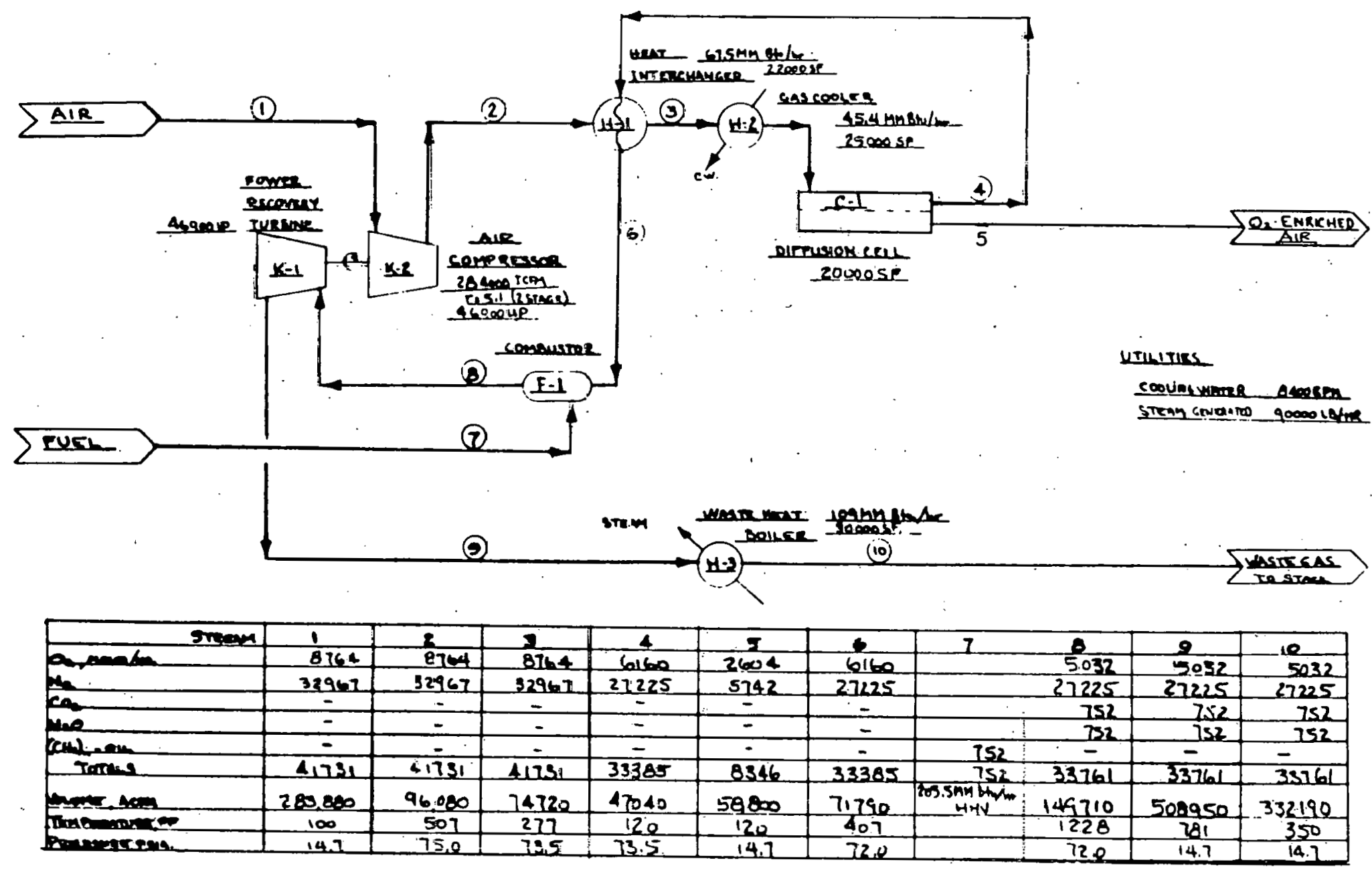

Fig. B-2. Process Flow Diagram for Pressure Diffusicn System

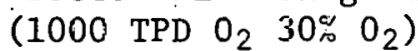


B. Factors Affecting the Membrane Performance

These are discussed in more detail in the Supplement. The basic conclusions developed there are:

- The oxygen concentration of the permeate increases as:

(1) The number of diffusion stages in serles increases

(2) The permeability ratio (ratio of the $\mathrm{K}_{i} \mathrm{~s}$ in $\mathrm{Eq} \cdot 1$ increases

(3) The pressure ratio (ratio of pressure after membrane to before membrane) decreases

(4) The percent recovery (moles permeate divided by moles feed $x$ 100) decreases.

- There is no significant difference in oxygen concentration for the three different gas flow modes in the diffusion cell. These include

(1) Permeate flowing countercurrently to residue

(2) Permeate flowing cocurrently with residue

(3) Premeate flowing crosswise to residue

Additionally, as the feed pressure increases, all other factors remaining the same, the component partial pressure differentials across the membrane increase, and according to Eq. 1, the membrane area decreases.

The sludy was limited to

- One-stage operation

- A membrane with an oxygen-to-nitrogen permeability ratio of 2 .

- $30 \% \mathrm{O}_{2}$ in the permeate

- A pressure ratio of 0.2

- Pressure vs. vacuum operation

These do not necessarily represent optimum conditions, and a future study to optimize the system would be worthwhile.

\section{Membrane Cel1 Design}

The membrane cell design initially proposed was fashioned after the spiral-wound systems developed for the reverse osmosis desalination process. This offers a compact and inexpensive approach. The differences between the two applications (reverse osmosis and gaseous diffusion) are important enough 
to impose significant differences in their respective designs. The most important factor relates to the relative volumetric fluxes. For reverse osmosis, this is of the order of $10 \mathrm{gpd} / \mathrm{ft}^{2}$. For gaseous diffusion, this is of the order of $2.5 \mathrm{scfm} / \mathrm{ft}^{2}$, which is about 3000-fold greater than for reverse osmosis. Additionally, the allowable pressure drops are more restricted for gas diffusion.

The impact of all of the above differences is that the gaseous diffusion cell will have to have larger flow channels before the membrane, and, especially, after the membrane. The units will require much more space, and will be more expensive than originally anticipated (see Appendix A). For present purposes, a conceptual diffusion cell design was developed, using multiple spiral membrane leaves with adequate diffusate channel space. Estimated capital costs were based on this design. Mnre definitive designs of this cell should be developed. These should be costed to confirm the est Imaces used in this study.

VII. PROM!n!39 ECONOMICS

\section{A. Capital Costs}

Estimated capital costs for a 1000 TPD $0_{2}$ (as $30 \%$ enriched air) plant are presented in Table $B-1$. This shows an estimated fixed capital for the vacuum system of $\$ 6,421,000$, which is $\$ 253,000$ less than that for the pressure system. This difference is not considered significant at this stage. The total estimated investment, which includes working capital, is $\$ 6,801,000$ for the vacuum system, or $\$ 333,000$ less than for the pressure. Again, this difference is not significant.

Table B-1. Capital Cost Estimate for Membrane Diffusinn Plant (1000 TPD $0.2,30 \% 0_{2}$ ); costs in $M \$, 1978$

\begin{tabular}{|c|c|c|}
\hline & $\begin{array}{c}\text { Vacuum } \\
\text { Operation }\end{array}$ & $\begin{array}{c}\text { Pressure } \\
\text { Operation }\end{array}$ \\
\hline Diffusion Cells & 1250 & 250 \\
\hline Compressors with Drivers & 629 & 5792 \\
\hline Vacuum Pumps with Drivers & 4542 & $\cdot-$ \\
\hline Heat Exchangers & -- & 592 \\
\hline Line Gas Heater & -- & 40 \\
\hline $\begin{array}{l}\text { Total Fixed Capita. } \\
\text { Working Capital }\end{array}$ & $\begin{array}{r}6421 \\
380\end{array}$ & $\begin{array}{r}6674 \\
460\end{array}$ \\
\hline Total Investment & 6801 & 7134 \\
\hline
\end{tabular}

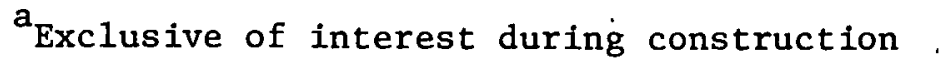

$b_{\text {Based on }} 2$ months out-of-pocket operating cost 
The capital estimate was developed by the following procedure:

- Diffusion cells - membrane estimated at $\$ 1 / \mathrm{ft}^{2}$ materials plus $100 \%$ for installation labor. Each membrane cell, containing $910 \mathrm{ft}^{2}$ was housed in a 5-ft dia $\times 8 \mathrm{ft}$ container with 3-12 in. IPS flanged connections for air in, diffusate and residue out; the container is full-flanged at one end to facilitate membrane replacement or repair. The cost of the container was based on estimated weight at $\$ 1 / 1 b$.

- All other equipment - from data in EA files

- Installation - from data in EA files for comparable components. This includes labor for process equipment installation plus materials and labor for
(1) Instrumentation
(2) Electrical
(3) Piping
(4) Foundations
(5) Structural, etc.

- Indirect Costs - Field Indirects estimated at $65 \%$ of direct field labor (from above). Home Office and Fee estimated at $15 \%$ of total field cost.

\section{B. Operating Costs}

Estimated operating costs for the two diffusion systems for producing $1000 \mathrm{TPD} \mathrm{O}_{2}$ (as $30 \%$ enriched air) are presented in Table B-2. The estimated cost, including return on investment, is $\$ 11.69 /$ ton $0_{2}$ for the vacuum system and $\$ 13.26 /$ ton $\mathrm{O}_{2}$ for the pressure system. The estimated $\$ 1.57 /$ ton $0_{2}$ difference in favor of the vacuum system could swing either way. For example, the difference would become zero if any one of the following possibilities occurred.

- Power cost was $3.3 \mathrm{c} / \mathrm{kWh}$ rather than the assumed $2.5 \mathrm{c}$

- By-product steam credit was $\$ 3.70 / \mathrm{M} 1 \mathrm{~b}$ rather than $\$ 3.00$

- There were no capital differences and

(1) power cost was $3.17 \mathrm{c} \mathrm{kWh}$, or

(2) steam credit was $\$ 3.62 / \mathrm{M} 1 \mathrm{~b}$

The bases for estimating operating costs are given in Table B-2. 
Table B-2. Operating Cost Estimate for Membrane Diffusion Plant.

$\left(1000\right.$ TPD $\left.0_{2}, 30 \% 0_{2}\right)$; costs in $\mathrm{M} / \mathrm{yr}, 1978$

\begin{tabular}{cc} 
Vacuum & $\begin{array}{c}\text { Pressure } \\
\text { Operation }\end{array}$ \\
\hline
\end{tabular}

Variable Costs

Power $(2.5 \mathrm{c} \mathrm{kWh})$

Fue1 ( $\$ 2.50 / \mathrm{MM} \mathrm{Btu})$

Cooling Water ( $5 \mathrm{c} / \mathrm{M}$ gal)

Steam $(\$ 3.00 / \mathrm{M} 1 \mathrm{~b})$

Túlal Varlable

Làital Independent Cosfs $s^{2}$.

Capital Dependent Costs

Total

$\$ /$ ton $\mathrm{O}_{2}$
1660

$--$

48

$\frac{--}{1.708} \quad \frac{(2160)}{2154}$

264

1926

$\overline{3898}$

11.69

$a_{2}$ men/shift at $\$ 132,000 / y r$ shift position (includes $\$ 7 / \mathrm{h}$ ), $30 \%$ payro11 burden, $10 \%$ direct supervision, $50 \%$ plant overhead)

$\mathrm{b}_{30 \%}$ of fixed capital per year ( $5 \%$ depreciation, $5 \%$ maintenance, $2.5 \%$ taxes and insurance, $17.5 \%$ before tax profit)

$\mathrm{c}_{\text {Based on }} 8000 \mathrm{~h} / \mathrm{yr}$ of capacity operation

\section{Comparison with Cryogenic Air Separation}

Table B-3 presents the capital and operating cost comparison for the two diffusion systems with cryogenic air separation, based on 1000 TPD $\mathrm{O}_{2}$ (as $30 \%$ enriched air). The estimated advantage for the diffusion systems is $\$ 2.11$ to $\$ 3.68 /$ ton $0_{2}$. This represents a $14-24 \%$ savings over current technology, and does not include potential additional savings through system optimization or through improved membrane development. In light of these and the initial estimated savings, the membrane diffusion system looks promising, especially for applications where oxygen enrichment, rather than pure oxygen is needed. 
Table B-3. Comparison of Economics for Oxygen Enrichment (1000 TPD $0_{2}, 30 \% 0_{2}$ ); costs in M\$, 1978

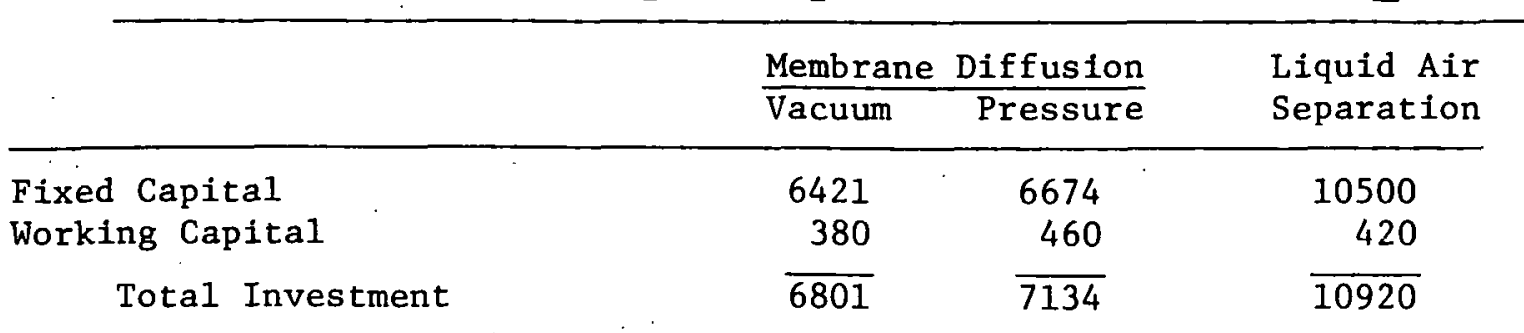

Operating Costs

Variable Costs

\begin{tabular}{rrrr}
1708 & & 2154 & 1710 \\
264 & & 264 & 264 \\
1926 & $\cdot$ & 2002 & 3150 \\
\hline 3898 & & 4420 & - \\
11.69 & 13.26 & 5124 \\
& & 15.37
\end{tabular}

Capital Independent Costs

Capital Dependent Costs

11.69

13.26

15.37

${ }^{a}$ Includes return on investment

VIII. PROCESS APPLICATIONS

A. MHD

In magnetohydrodynamic (MHD) power generation, an electrically conducting gas is passed through a duct at high speed in the presence of a transverse magnetic field. The electromotive forces induced in the gas allow current to be extracted by appropriately located electrodes, and delivered to an external load circuit. To ionize the gases to an appropriate level (about $10^{14}$ electrons/cc), one must achieve a gas temperature of $4000-5000^{\circ} \mathrm{F}$ in the presence of seeding materials which have low ionization potentials (e.g., potassium or cesium).

The key to the process is achieving inlet gas temperatures of about $5000^{\circ} \mathrm{F}$. To do this with dry air requires an air preheat temperature of $2510^{\circ} \mathrm{F}$, assuming no heat losses. To achieve such temperatures requires solving. the following almost insurmountable problems:

- Develop refractories which will operate at peak temperatures of about $2800^{\circ} \mathrm{F}$ and not be fluxed by molten coal ash, and

- Develop air switching valves (circa 12-15 ft dia) which can rapidly switch preheated air (at $2500^{\circ} \mathrm{F}$ ) or hot combustion gases (at $2800^{\circ} \mathrm{F}$ ); these valves are required to switch the large refractory "stoves" from the heat-up phase to the afr pre-heat phase of the cycle, and vice versa.

Nothing appears on the horizon for the first problem. The second problem can be engineered at enormous cost, but the reliable life of such a device will be questionable. 
On the other hand, using $30 \% \mathrm{O}_{2}$-enriched air requires an air preheat temperature of only $1280^{\circ} \mathrm{F}$. This is well within modern, blast-furnace technology. Further, there is no preheat necessary for $37 \% 0_{2}$-enriched air.

The use of oxygen-enriched air for MHD would be an extremely attractive application. Some calculated parameters around such an application are given in Table B-4, which indicates enriched air requirements of 14,00016,000 TPD $\mathrm{O}_{2}$ for a 1000-MW MHD - steam power plant, as outlined in Fig. B-3.

\section{B. Iron Blast Furnaces}

Considerable development work has been applied to using oxygen-enriched air for iron blast furnaces. Process economics are possible up to ahout 25\% $\mathrm{O}_{2}$ in the blast. Very preliminary estimates indicate that at this $\mathrm{O}_{2}-1$ evel:

Blast furnace capacity would be increased by about $16 \%$

Energy savings, due to elimination of heat to air preheat stoves, would be about $0.7 \mathrm{MM} \mathrm{Btu/ton}$ iron (equal to cost of enrichment).

Above $25 \% \mathrm{O}_{2}$, excessive temperatures are generated in the smelting zone, and these would lead to inoperable conditions caused by burden-bridging in the shaft. The main obstacle to using oxygen-enrichment has heen rost. The membrane-diffusion approach may overcome that.

Table B-4. Effect of Oxygen Enrichment on MHD

Steam Power Plant Requirements,

$1000 \mathrm{MW}$

\begin{tabular}{|c|c|c|c|}
\hline & Air & $30 \% \quad 0_{2}$ & $40 \% \mathrm{O}_{2}$ \\
\hline $\begin{array}{l}\text { Preheat air temperature, }{ }^{\circ} \mathrm{F}^{\mathrm{a}} \\
\text { Energy extracted, MM Btu/h }\end{array}$ & 2510 & 1280 & $100^{\mathrm{b}}$ \\
\hline MHD Cycle & 2058 & 1783 & 840 \\
\hline Steam Power Cycle & 3086 & 3714 & 5857 \\
\hline Air Preheat & 3007 & 1102 & -- \\
\hline Total & $\overline{8151}$ & $\overline{6599}$ & $\overline{6397}$ \\
\hline \multicolumn{4}{|l|}{ Power. Output MM Bțug/h } \\
\hline MHD Cycle & 2058 & 1783 & 840 \\
\hline Steam Power Cycle & 1359 & 1634 & 2577 \\
\hline Total & $\overline{34.1 .7}$ & $\overline{3417}$ & $\overline{3417}$ \\
\hline Thermal Efficiency & 63.5 & 56.7 & 49.1 \\
\hline Oxygen required, TPD & 12750 & 14270 & 16500 \\
\hline
\end{tabular}




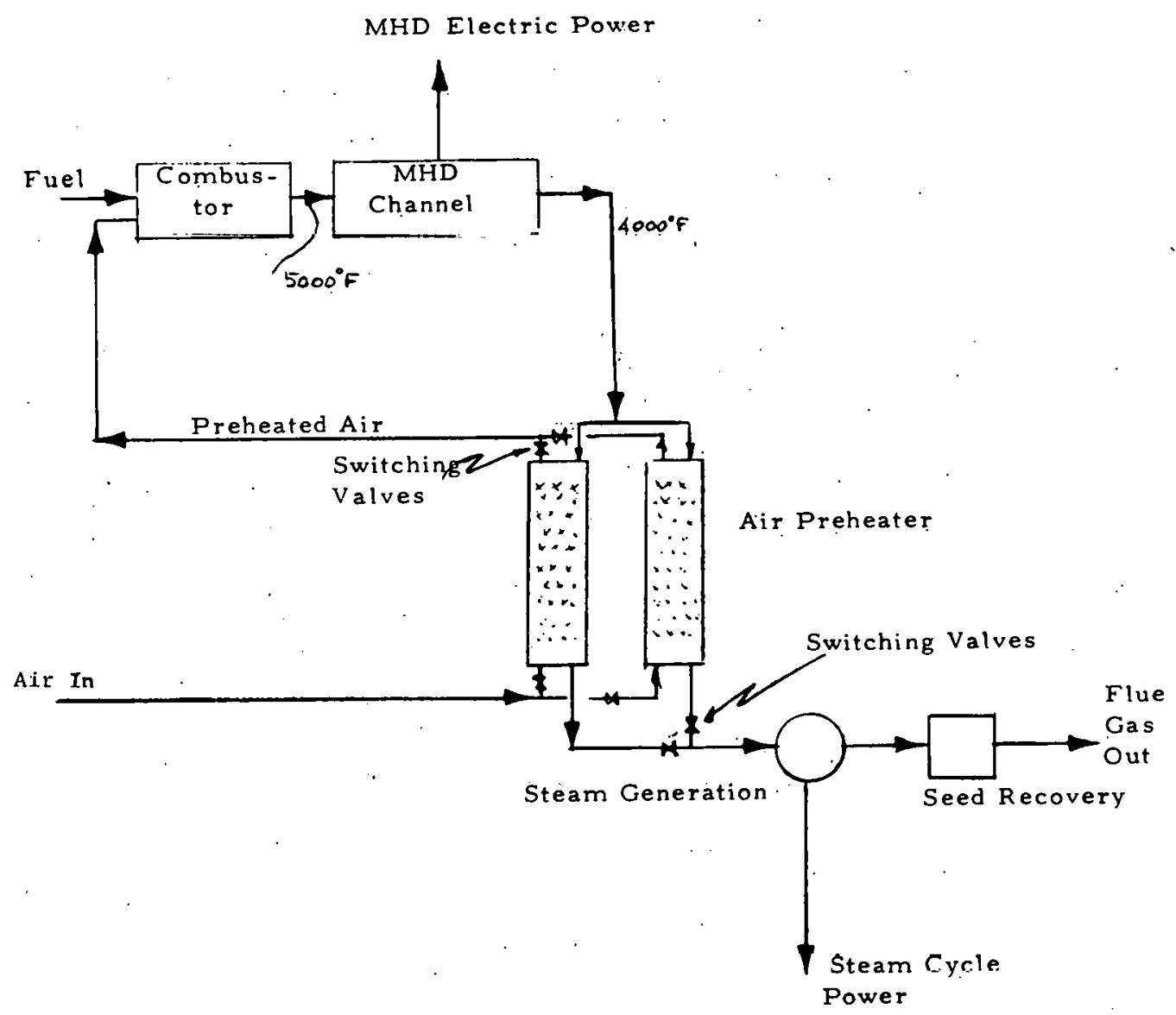

Fig. B-3. MHD Power Cycle

The potential oxygen consumption for a modern 1 MM TPY blast furnace, using $25 \% \mathrm{O}_{2}$, is about $510 \mathrm{TPD}$. This can be supplied by a diffusion plant producing 270 TPD $0_{2}$ (as $30 \% \mathrm{O}_{2}$ ) blended with air to make up the difference. The potential oxygen-enriched air consumption in U.S. blast furnaces could be as high as 50,000 TPD (as $30 \% 0_{2}$ ), based on current steel production of 200 MM TPY.

Additional analysis of this application would be worthwhile. For example, a basic engineering analysis would better define the limits and economic advantages for oxygen enrichments. It would also be worthwhile to extend this application to other sectors of the steel industry, e.g., steelmaking, ferroalloys, etc. 


\section{Coal Gasification}

The manufacture of low Btu fuel gas ( $150 \mathrm{Btu} / \mathrm{scf}$ ) is the only potential place where oxygen-enriched air could find application. There appears to be no role for it in the production of high Btu ( $1000 \mathrm{Btu} / \mathrm{scf})$ or intermediate Btu ( $350 \mathrm{Btu} / \mathrm{scf})$ gas since:

- Either pure oxygen is required to eliminate unwanted nitrogen dilution, or

- A moving burden process (such as COGAS, Battelle Carbide or $\mathrm{CO}_{2}$ Acceptor) uses air for combustion, and there is no significant energy savings when using oxygen enrichment.

The advantage of using oxygen-enriched air resides mainly in making a slightly higher-Btu gas--of the order of $30 \%$ higher or about $45 \mathrm{Btu} / \mathrm{scf}$ more.

The higher Btu-value may enable savings in

- Gas distribution

- Gas clean-up

- Gasifier capital

off-setting these will be an estimated cost of about $\$ 0.75 / \mathrm{MM}$ Btu fuel gas for oxygen enrichment (based on $\$ 12 /$ ton $0_{2}$ as $30 \%$ oxygen):

The potential savings for the above are:

- Gas distribution - 1.bc/MM Btu (based on LU-mile piping and 1ç/MCF plping cost).

- Gas clean-up - 2.0c/MM Btu (max) (based on decreased $\mathrm{CO}_{2}$ formed equivalent to lower heat to $\mathrm{N}_{2}$ in gasifier and $15 \mathrm{cmol} / \mathrm{CO}_{2}$ to remove this added $\mathrm{CO}_{2}$ ).

- Gasifier capital - 30c/MM Btu (high spot), (based on high spot gasifier capital cost of $\$ 2 \mathrm{MM}$ for $500 \mathrm{MM} \mathrm{Btu/d}$ with air and $\$ 1.8 \mathrm{MM}$ with enriched-air and $25 \%$ per year capital related costs).

In summary, there appears to be little incentive for using oxygenenriched air for coal gasification.

D. Fuel Cells

The only advantage for oxygen-enrichment for this application is reduction in the nitrogen in the combustion off-gases. Oxygen enrichment will not increase the fuel cell efficiency. It will reduce the heat leaving in the combustion off-gases (by the reduction in nitrogen), and hence will increase the heat picked up by the cooling jacket. The added jacket cooling load will present a minor engineering design problem. The value of the added recovered heat will be small - only about 6C/MM Btu in (as hydrogen at $\$ 4.50 / \mathrm{MM} \mathrm{Btu})$. This will not cover the cost for the oxygen-enriched air (estimated to be $92 c \mathrm{MM}$ Btu in assuming $\$ 12 /$ ton $0_{2}$ as $30 \% 0_{2}$ ). 
In summary, there appears to be no incentive for using oxygen-enriched air for fuel cells. 
SUPPLEMENT TO APPENDIX B

ANALYSIS OF FACTORS AFFECTING MEMBRANE PERFORMANCE 


\section{ANALYSIS OF- FACTORS AFFECTING MEMBRANE PERFORMANCE}

There are five major factors which affect the gas separation membrane performance as expressed by oxygen concentration in the permeate. These are:

- Permeability ratio

- Number of membrane stages in series

- Ratio of pressure downstream to upstream pressure

- Relative flow of permeate vis-a-vis the flow of air or residue.

At least three modes are possible:

(1) Cocurrent flow

(2) Countercurrent flow

(3) Cross-flow

- Percent recovery of permeate

This supplement presents analyses of these factors.

The membrane surface requirements are affected by the above and by the following additional factors:

- Inlet gas pressure - this together with the pressure ratio defines the pressure differential across the membrane

- Membraire thickness

- Membrane permeability

The inlet pressure was considered in the body of the report and will not be treated further in this supplement.

Effect of Permeability Ratio and Number of Stages on Oxygen Enrichment. Figure S-1 presents the calculated limiting (maximum) oxygen concentration in the permeate as a function of permeability ratio $(\alpha)$ and number of stages (n). These calculations are based on: zero recovery of permeate; the stages in series with no recycle of residues to previous upstream stages; and a zero pressure ratio (downstream pressure/upstream pressure). On the basis of these assumptions, the following equation was derived, which relates the oxygen concentration $\left(X_{n}\right)$ in the permeate of the $n$th stage to permeability ratio $(\alpha)$ and number of ${ }^{n}$ stages $(n)$.

$$
x_{n}=\frac{\alpha^{n} x_{0}}{\left(\alpha^{n}-1\right) x_{0}+1}
$$




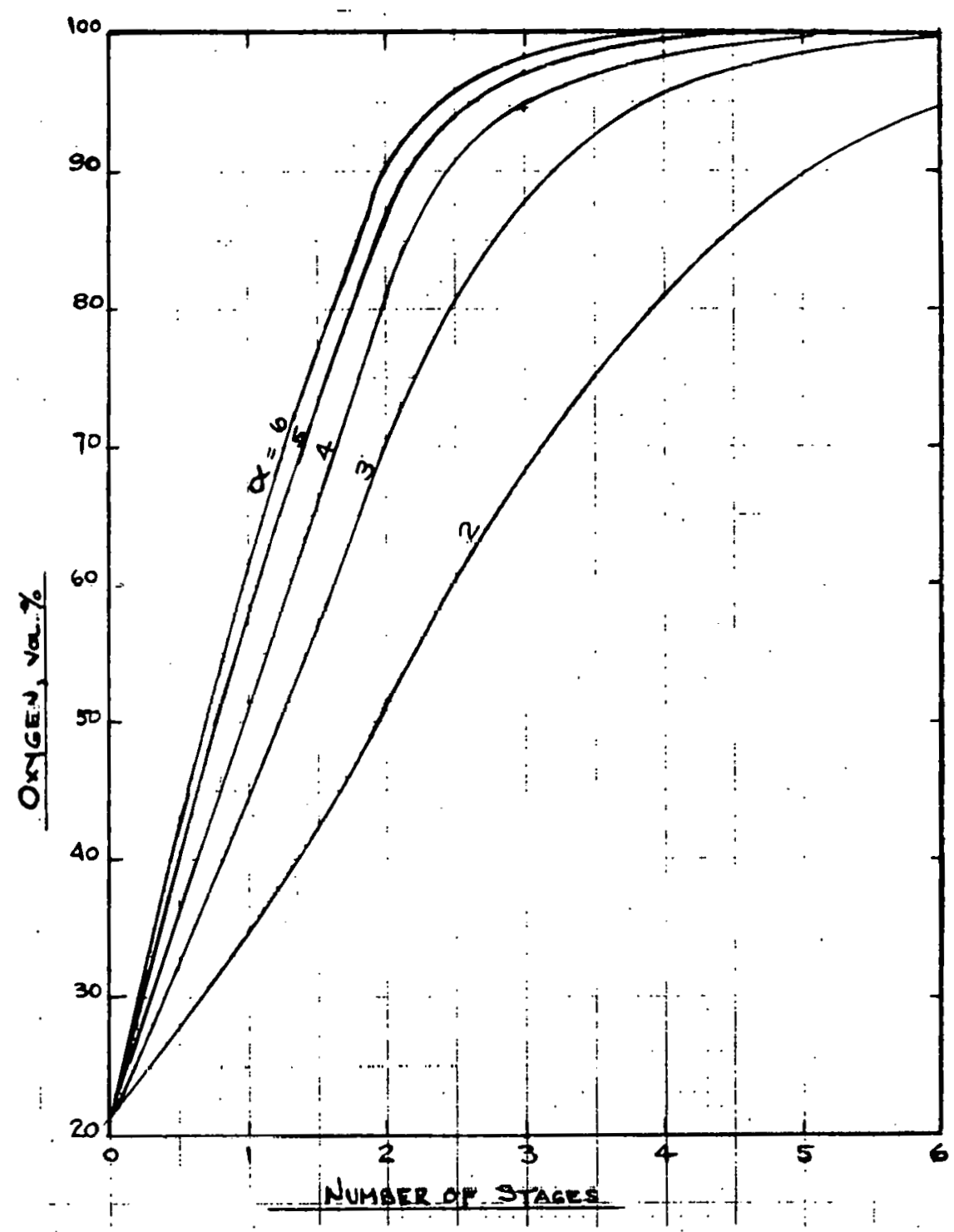

Fig. S-1. Calculated Effect of Permeability Ratio $(\alpha)$ and Number of Stages on Limiting Oxygen Concentration in the Permeate

The oxygen concentration calculated from this equation is the maximum to be expected. As the recovery of permeate increases, and as the pressure ratio increases, the oxygen enrichment per stage decreases. The effect of increasing recovery and pressure ratio for the various flow modes follows:

Erfect Uf PrcGourc Rat1o and kecovery on Uxygen Enrichment for Cocurrent Flow. Figure S-2 presents the calculated effect of pressure ratio and permeate recovery on oxygen in the permeate for cocurrent flow and a permeability ratio of 2 . This figure shows that the oxygen concentration in the permeate decreases with increasing permeate recovery and with increasing pressure ratio. The diagrammatic model of this system is shown in Fig. S-3.

The derived analytical relationships describing the effect of pressure ratio and recovery of permeate on oxygen enrichment for one-stage with normal air feed, and cocurrent flow of permeate and residue are as follows: 


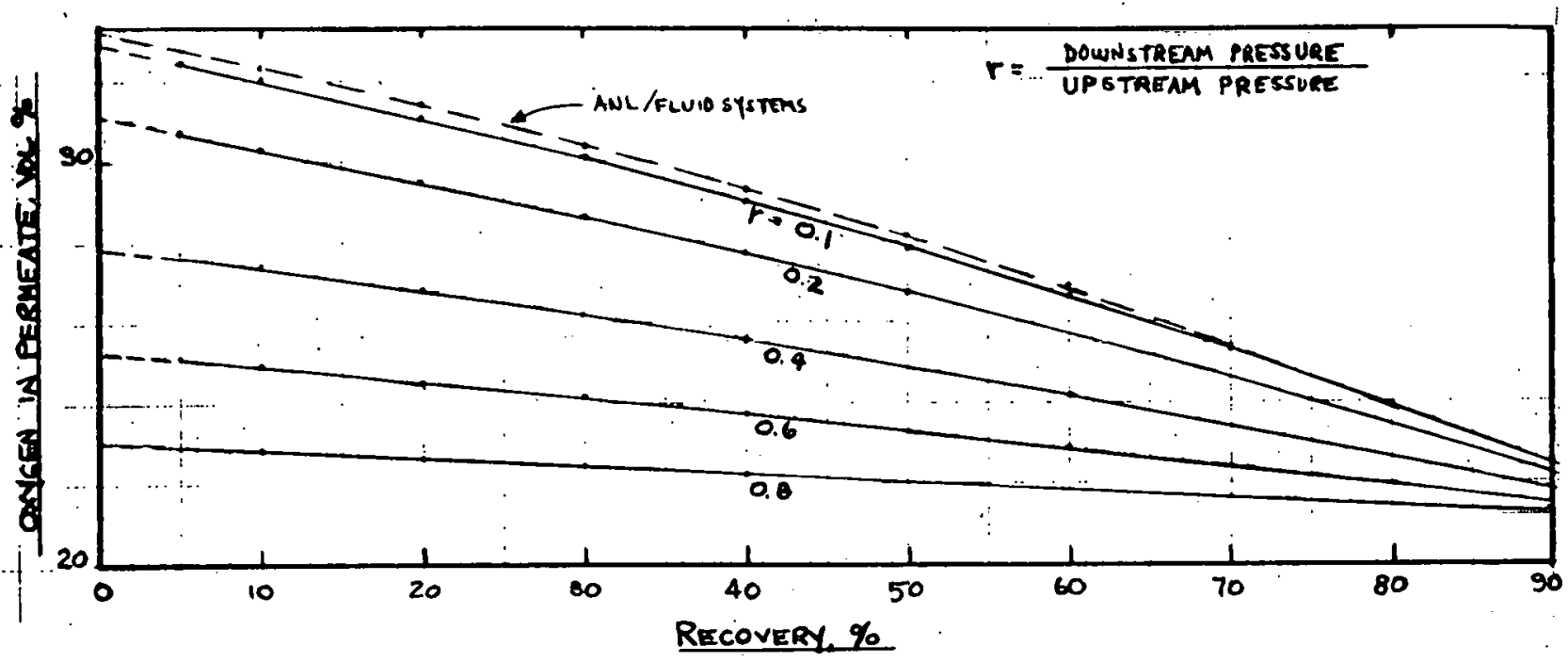

Fig. S-2. Calculated Effect of Recovery and Pressure Ratio on Oxygen Concentration in Permeate for $\alpha=2$ and Cocurrent Flow

$$
\frac{X}{P-X}=\frac{\alpha\left[0.21+\frac{21-X}{100-P}-\frac{X r}{P}-w\right]}{1.79-2 r-\frac{21-X}{100-P}+\frac{X r}{P}+w}
$$

where $\mathrm{w}$ is the mole fraction of $\mathrm{O}_{2}$ in the permeate at the air-feed end (see Fig. S-3), and is given by:

$$
w=(r+1.21)-\sqrt{(r+1.21)^{2}-1.68 r}
$$

$$
2 \text {. }
$$

and where:

$\alpha=$ permeability ratio

$\mathrm{X}=$ oxygen concentration in permeate, mol. \%

$r=$ pressure ratio $=$ pressure after membrane/pressure before membrane

$P=$ recovery of permeate, mol $\%$ of feed

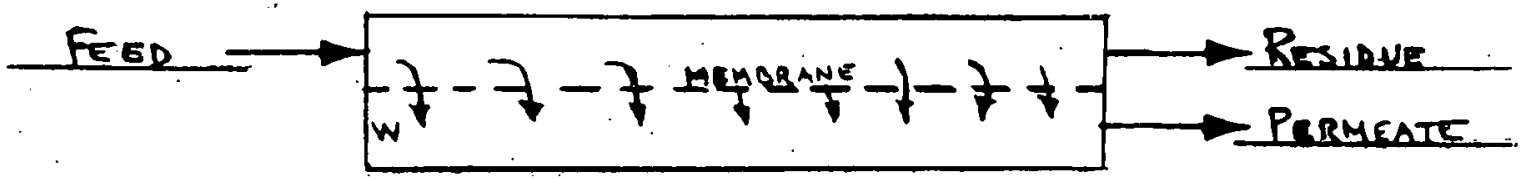

Fig, S-3, Gas Diffusion with Cocurrent Flow of Permeate and Residue 
These expressions are derived using the arithmetic mean partial pressure differentials of $\mathrm{O}_{2}$ and $\mathrm{N}_{2}$. - This appears to be perfectly admissible for moderate permeate recoveries and pressure ratios. For the following combinations, the arithmetic mean was within $10 \%$ of the $10 \mathrm{~g}$ mean, which would be more rigorous to use, but extremely. more cumbersome to handle.

\begin{tabular}{cc}
$\mathrm{r}$ & $\mathrm{P}(\max ), \operatorname{mol} \%$ \\
\hline 0.1 & 80 \\
0.2 & 80 \\
0.4 & 60 \\
0.6 & 15
\end{tabular}

The curves in Fig. S-2 for values greater than the combinations noted are approximate.

Also included in Fig. S-2 are ANL unpublished data on oxygen enrichment plotted against percent recovery for $r=0.10$. The experimental line agrees reasonably well with the calculated line; the slight difference can probably be explained on the basis that the actual permeability ratio of the experimental membrane is slightly greater than the assumed value at 2 .

Effect of Pressure Ratio and Recovery on Oxygen Enrichment for Countercurrent Flow. Figure S-4 presents the calculated effect of pressure ratio and permeate recovery on oxygen in the permeate, for countercurrent flow and a permeability ratio of 2 . The effects on $\mathrm{O}_{2}$ concentration are approximately the same, at comparable conditions as calculated for cocurrent flow. The diagrammatic model of this sytem is shown in Fig. S-5.

The derived analytical relationship describing the effect of pressure ratio and permeate recovery on oxygen enrichment for one stage with normal air feed, and countercurrent flow of permeate and residue is the same as Eq. S-2, wherc

$$
\mathrm{w}=\frac{\left[I+\frac{21-X}{100-P}+1\right]-\sqrt{\left[1+\frac{21+X}{100-P}+1\right]^{2}-\frac{8 r(21-X)}{100-P}}}{2}
$$

As before, the derived equations are based on the arithmetic mean partial pressure differentials. The region where the arithmetic mean and lng mean are within $10 \%$ of each other is approximately as described above for the rocurrent. f1nw mode.

Effect of Pressure Ratio and Recovery on Oxygen Enrichment for Cross Flow. Figure S-6 presents the calculated effect of pressure ratio and permeate recovery on oxygen in the permeate for cross-flow and a permeability ratio of 2 . The same trends are observed here as for the cocurrent and countercurrent flow modes. In passing, it should be noted that the membrane design suggested by Fluid Systems uses cross-flow, as shown in Fig. $\mathrm{S}-7$. 


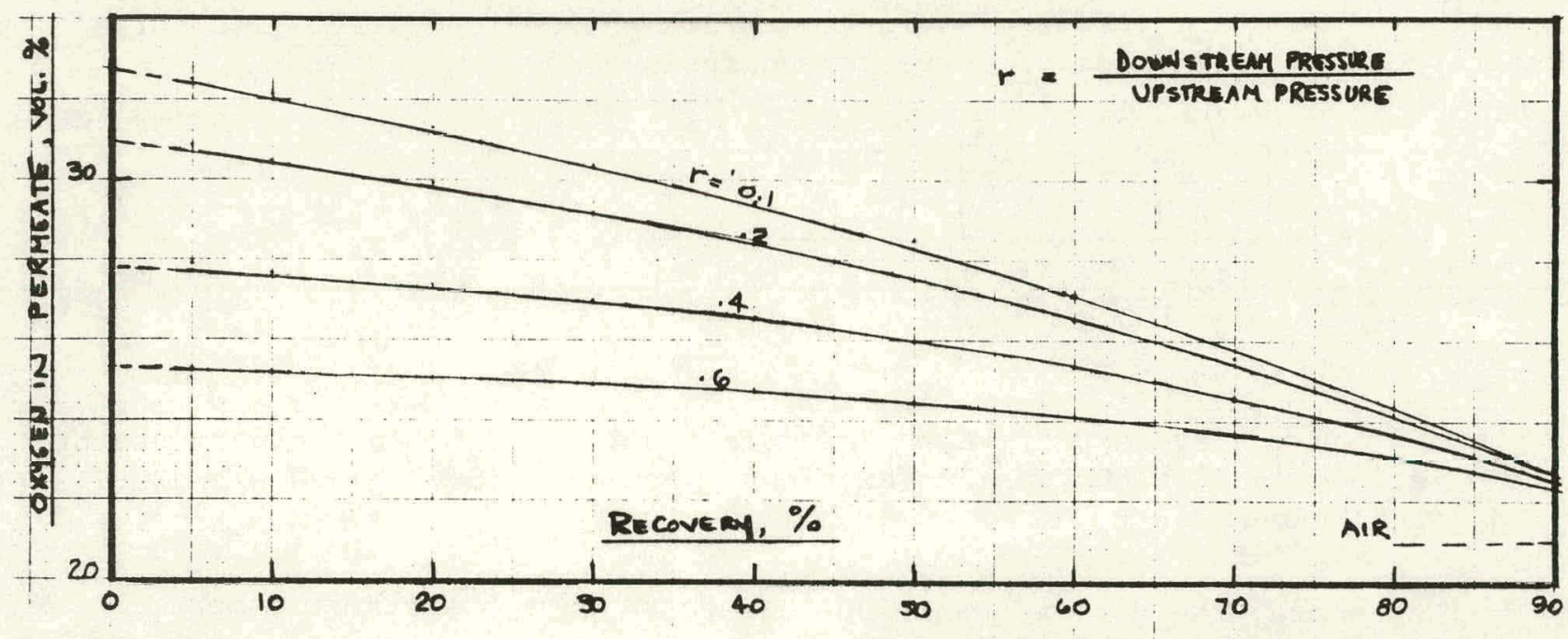

Fig. S-4. Calculated Effect of Recovery and Pressure Ratio (r) on Oxygen Concentration in Permeate for $\alpha=2$ and Countercurrent Flow

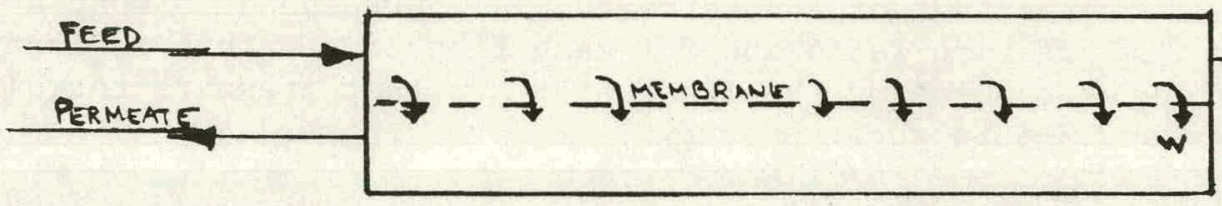

Fig. S-5. Gas Diffusion Cell with Countercurrent Flow of Permeate and Residue

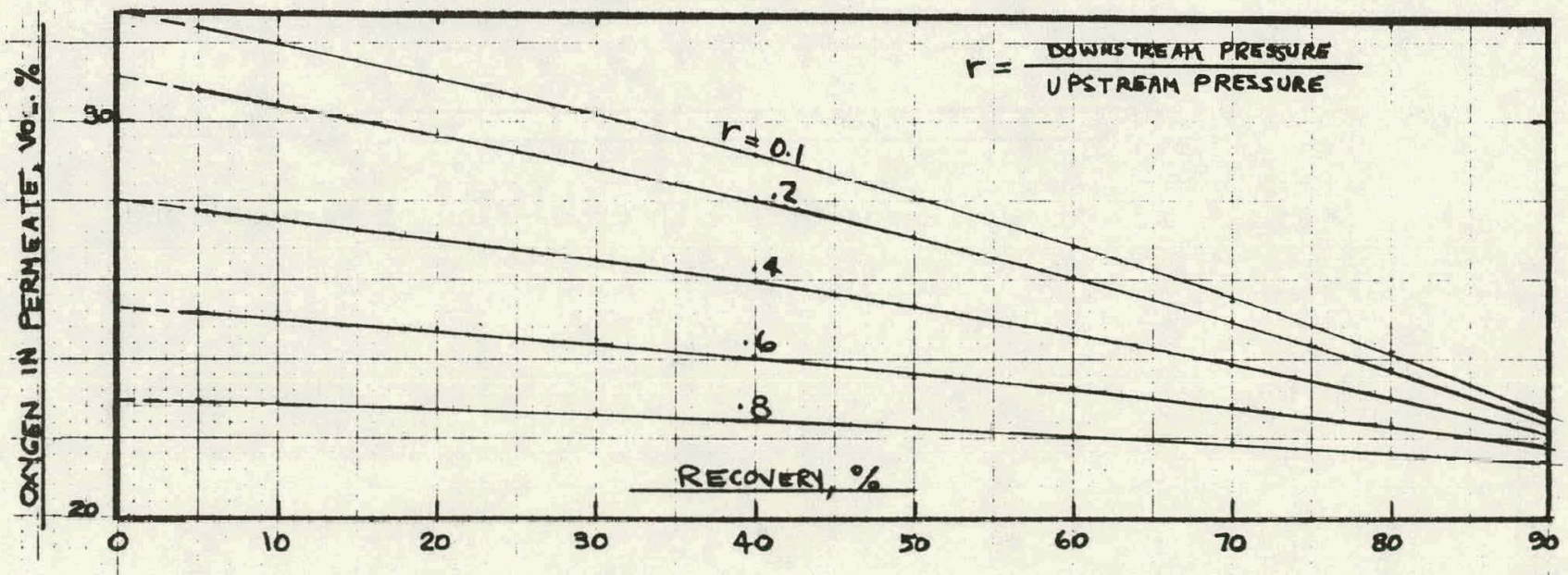

Fig. S-6. Calculated Effect of Recovery and Pressure Ratio ( $r$ ) on Oxygen Concentration in Permeate for $\alpha=2$ and Cross-F1ow 
The derived analytical relationship describing the effect of pressure ratio and permeate recovery on oxygen enrichment for one stage with normal air feed and cross-flow of permeate and residue is

$$
\frac{X}{P-X}=\frac{\alpha\left[\frac{42-0.21 P-X}{100-P}\right]-w-V}{\frac{158-1.79 P+X}{100-P}-2 r+w+V}
$$

where $\mathrm{w}$ and $\mathrm{v}$ are, respectively, the mole fraction of $\mathrm{O}_{2}$ in the permeate at the feed-end and at the residue exit-end. Equation ( $\mathrm{S}-4)$ gives $\mathrm{w}$ and Eq. $\mathrm{Eq} \cdot(\mathrm{S}-5)$ gives $\mathrm{V}$.

As before, the derived equations are based on the arithmetic mean partial pressure differentials. The regions where the arithmetic mean and log mean are within $10 \%$ of each other is approximately as described above for the cocurrent flow mode.

Effect of Pressure Ratio and Flow Mode on Limiting Oxygen Enrichment Fig. S-8 presents the effect of pressure ratio and flow modes on the maximum oxygen content of the permeate. This figure was derived by noting that the maximum oxygen content of the permeate will correspond to that at zero recovery for any pressure ratio and for each flow mode. This content is then estimated by extrapolating the lines (for constant pressure ratio) in Figs. S-2, $\mathrm{S}-4$, and $\mathrm{S}-6$ to zero recovery.

Figure S-8 indicates that the limiting oxygen content decreases with increasing pressure ratio, and is independent of the flow mode.

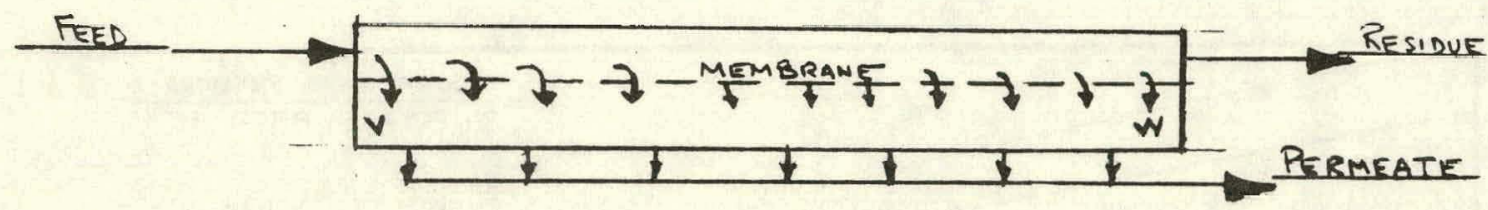

Fig. 5-7. Gas Diffusion Cell with Cross-Flow of Permeate and Residue 


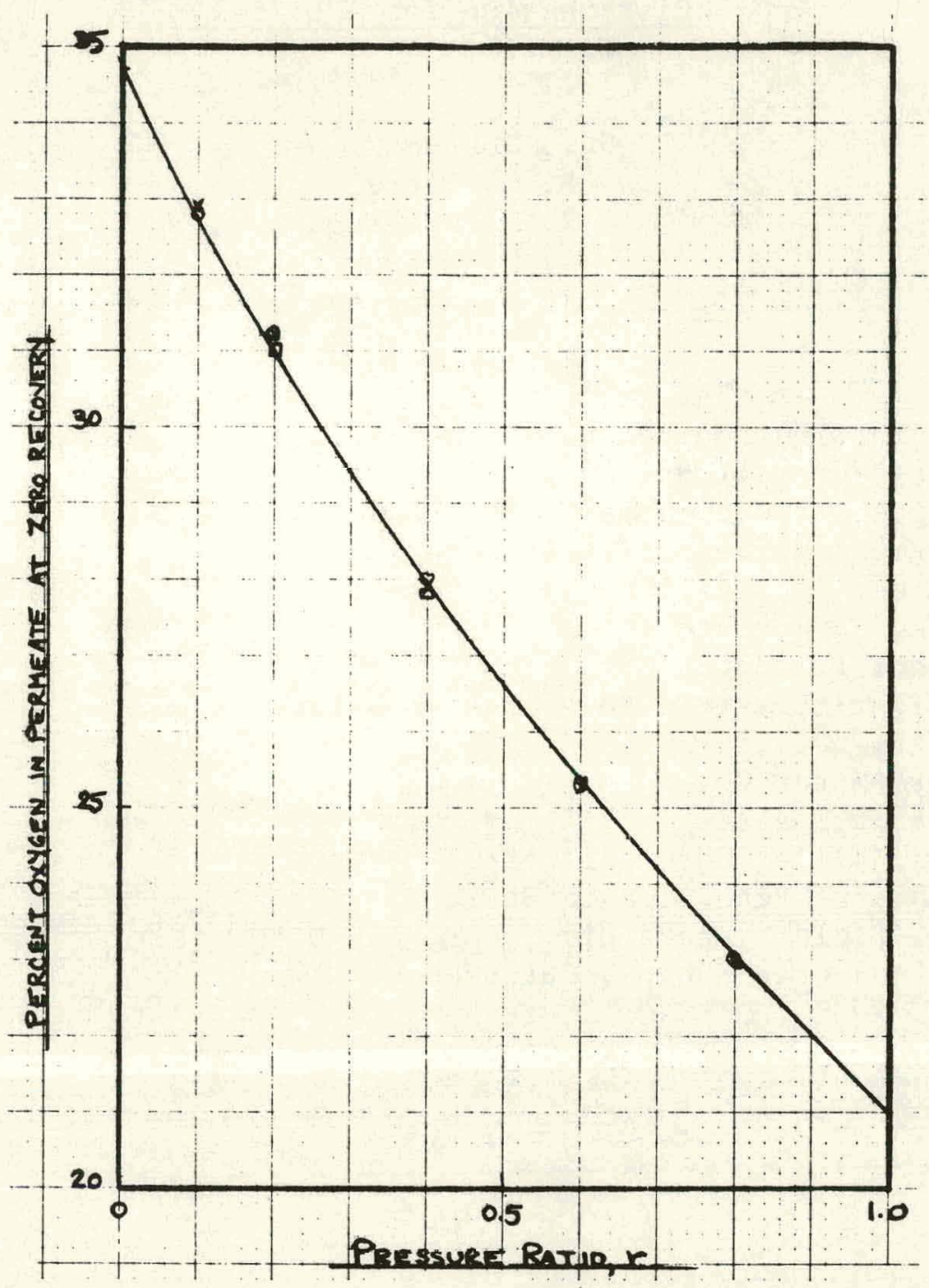

Fig. S-8. Effect of Pressure Ratio on Oxygen Content of Permeate at 7.ero Recovery. 
Distribution for ANL-78-108

Internal:
J. Fischer (15)
A. A. Jonke
D. S. Webster
L. Burris
T. R. Johnson

\author{
I. Johnson \\ R. D. Pierce \\ J. P. Ackerman \\ G. M. Kesser \\ J. J. Roberts
}

\author{
J. E. Young \\ A. B. Krisciunas \\ ANL Contract File \\ ANL Libraries (5) \\ TIS Files (6)
}

\section{Externa1:}

DOE-TIC, for distribution per UC-90f and $-95 \mathrm{~g}$ (403)

Manager, Chicago Operations and Regional Office, DOE Chief, Office of Patent Counsel, DOE-CORO President, Argonne Universilies Assuciation

Chemical Engineering Division Review Committee:

C. B. Alcock, U. 'loronto

R. C. Axtmann, Princeton U.

R. E. Balzhiser, Electric Power Research Inst.

J. T. Banchero, U. Notre Dame

T. Cole, Ford Motor Co.

P. W. Gilles, U. Kansas

R. I. Newman, Allied Chemical Corp.

G. M. Rosenblatt, Pennsylvania State U.

L. J. Burnett, Fluid Systems Div., UOP, San Diego (15)

F. Corban, Inland Steel Corp., Chicago 